
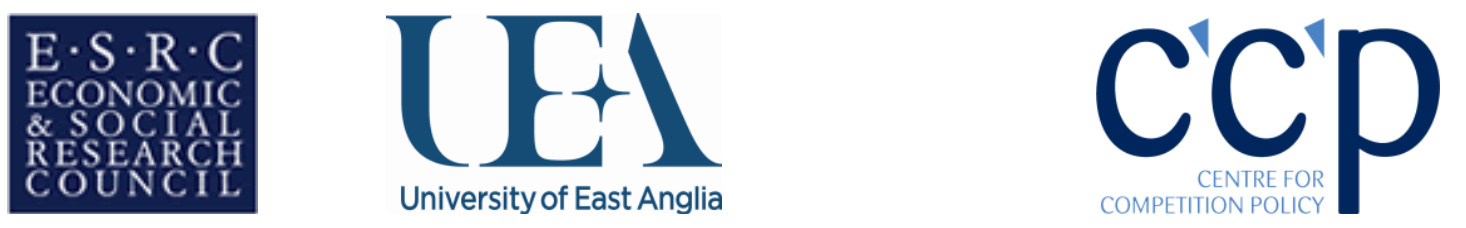

\title{
Injunctive Relief and Private Antitrust Enforcement
}

(Work in progress - please do not quote without permission)

\section{Sebastian Peyer}

\section{CCP Working Paper 11-7}

\begin{abstract}
The paper analyses the role of injunctions in the private enforcement of competition law. Most commentators deal predominantly with damages actions and the European policy proposals only discuss the conditions for successful compensation claims. However, damages claims are likely to be the most expensive and time consuming remedy available. In many cases injunctive relief may be cheaper and, thus, be preferred by the victim. Asking the court to order the perpetrator to either cease from certain behaviour or to undertake certain actions, plaintiffs might be willing to forego compensation in exchange for a quicker dispute solution with effect for the future. The variety and flexibility of injunctive relief injunctions can be granted on a preliminary basis or permanently, contain a prohibition or being mandatory - provides victims of anticompetitive conduct with a multi-functional tool to seek relief. The paper compares the usage of and the legal framework for injunctive relief in England and Wales and Germany. The antitrust litigation data available for both jurisdictions indicate that the use of injunctive relief in English and German courts differs greatly. Analysing the legal framework for injunctive relief, I will look at the judicial approach that is taken with respect to injunctions and the possible reason for a varying usage of this remedy.
\end{abstract}

Acknowledgements: The support of the ESRC Centre for Competition Policy and the Faculty of Social Sciences is gratefully acknowledged. I would like to thank Dan Crane, Simon Deakin, Andy Gavil, Michael Harker and Morten Hviid for their comments. The support of the Economic and Social Research Council is gratefully acknowledged. 
Contact Details:

Sebastian Peyer, Doctoral research fellow at the ESRC Centre for Competition Policy \& Norwich Law School, University of East Anglia. Comments are welcome at s.peyer@uea.ac.uk 


\section{Contents}

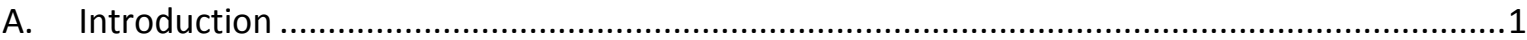

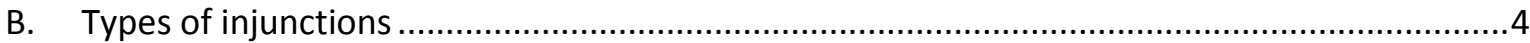

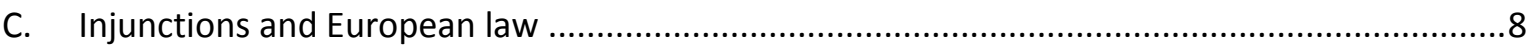

D. Injunctions in German antitrust law ...................................................................... 14

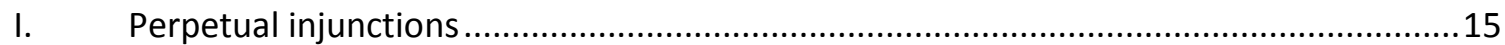

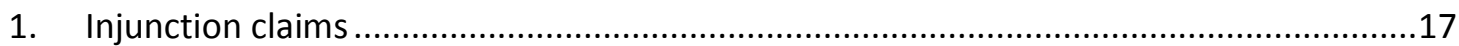

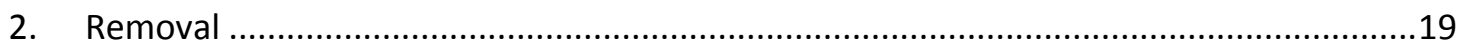

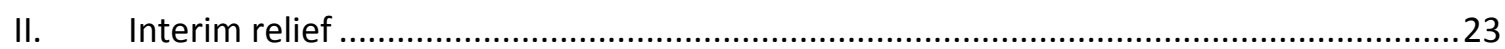

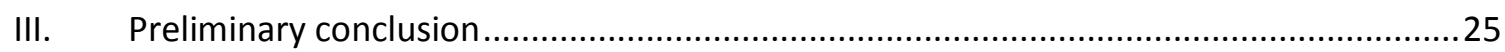

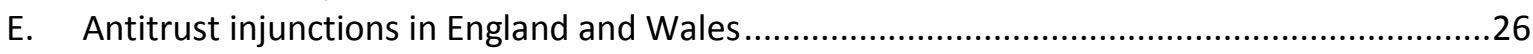

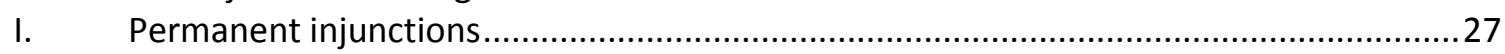

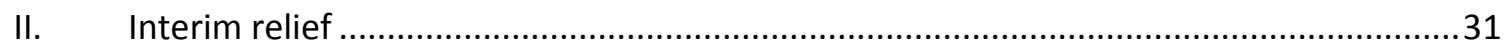

III. Preliminary conclusion...................................................................................43

F. Comparing the grant of injunctive relief in Germany and England and Wales ....................45

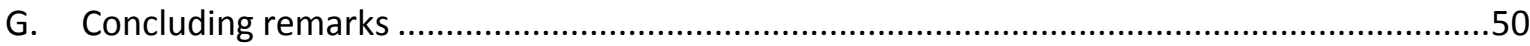


"Today, private enforcement is a widely-known and widely-used procedure, and most lawyers and businessmen are fully cognizant of its effectiveness. But even today, most private litigation involves an attempt to obtain treble damages, and private thinking seems to have become channeled along that line. This is unfortunate, for the availability of injunctive relief, either alone or combined with an action for treble damages, offers the private litigant a most flexible and valuable remedy against existing or threatened antitrust violations." ${ }^{1}$

\section{A. Introduction}

Endowing individuals with a private right for actions, private antitrust enforcement is often associated with damages actions; that are monetary payments for a loss suffered in the past. But what if the victim of anticompetitive conduct does not have an interest in payments for past harm but rather fixes the issue with effect for the future? And if the victim's means are limited, would it not be more economical to seek other than expensive damages relief? Injunctive relief provides for a different antitrust remedy although it is often overlooked. It does not substitute claims for damages but it has its own purpose in antitrust litigation. Interestingly, the debate about the private enforcement of the antitrust rules, particularly in Europe, is spun around actions for compensatory payments. The efforts of the European Commission to strengthen private antitrust actions in Europe exemplify this. Outlining its policy proposals in the White Paper, the European Commission aims exclusively at the improvement of the damages remedy although it was conceded earlier that injured parties could seek injunctions as well. ${ }^{2}$ The shadowy existence of injunctive relief is remarkable because the lack of interest in this type of antitrust relief does not appear to have a clear reason. Private antitrust injunctions in Europe hardly spark academic interest and seem to be broadly underrated. ${ }^{3}$ In his book on EC private antitrust enforcement, Komninos devoted 54 pages to

\footnotetext{
${ }^{1}$ Everette MacIntyre, 'Antitrust Injunctions: A Flexible Private Remedy' (1966) Duke Law Journal 22-40, 22.

${ }^{2}$ Denis Waelbroeck, Donald Slater and Gil Even-Shoshan, 'Study on the Conditions for the Claims of Damages in Case of Infringement of EC Competition Rules, Comparative Report' (Brussels 2004) http://ec.europa.eu/competition/antitrust/actionsdamages/comparative_report_clean_en.pdf accessed 30 September 2010; European Commission, 'Green Paper - Damages Actions for Breach of the EC Antitrust Rules' (Brussels 2005) http://ec.europa.eu/comm/competition/antitrust/actionsdamages/documents.html\#greenpaper accessed 30 September 2010; European Commission, 'White Paper on Damages Actions for Breach of the EC Antitrust Rules' (Brussels 2008) http://ec.europa.eu/competition/antitrust/actionsdamages/documents.html\#whitepaper accessed 30 September 2010. Injunctions were mentioned in the Staff Working Paper accompanying the Green Paper, European Commission, 'Commission Staff Working Paper, Annex to the Green Paper Damages Actions for Breach of the EC Antitrust Rules' (Brussels 2005) http://ec.europa.eu/comm/competition/antitrust/actionsdamages/documents.html\#staffpaper accessed 26 March 2010 para 16.

${ }^{3}$ Barry J Rodger and Angus MacCulloch, 'Wielding the Blunt Sword: Interim Relief for Breaches of EC Competition Law before the UK Courts' (1996) 17 European Competition Law Review 393-402; Wulf-Henning
} 
the damages remedy and only three to permanent injunctions although, one must admit in fairness, that he regards injunctions as an integral part of private antitrust enforcement. Sometimes the neglect of antitrust injunctions may stem from the difficulties analysing them. In their book on antitrust penalties in the United States, Elzinga and Breit did not consider the vast majority of injunctions while assessing antitrust instruments because, among other reasons, the variety of injunctions posed difficulties for their analysis. ${ }^{4}$ At least they implicitly acknowledged that injunctive relief exists in multiple shapes and that it has its place in private antitrust. Maclntyre's observation that we are mostly concerned with damages actions is still valid today although it was made more than 40 years ago and with respect to private antitrust enforcement in the United States.

The purpose of this paper is to draw the attention to private antitrust injunctions. More precisely, I will compare the role of injunctive relief for breaches of competition law in England and Wales and Germany. Not only is it difficult to understand why private antitrust enforcement is only measured on the success of damages actions; recent data from both England and Germany, I have summarised in table 1, also show that the use of injunctive relief differs significantly between these two jurisdictions. Rodger discovered only a handful of cases in which plaintiffs sought permanent or interim injunctions. ${ }^{5}$ In contrast to Rodger's findings, the German data show a widespread use of injunctive relief in antitrust proceedings. This comprises of both permanent and preliminary remedies which are made available to victims of anticompetitive conduct. This observation - very few plaintiffs seek injunctions in England while the majority of German antitrust case is based on injunctive relief - provides the starting point for my comparative analysis.

Roth, 'Das Kartelldeliktsrecht in der 7. GWB-Novelle' in Theodor Baums and others (eds), Festschrift für Ulrich Huber: Zum siebzigsten Geburtstag (Mohr Siebeck, Tübingen 2006) 1133; Assimakis P Komninos, EC Private Antitrust Enforcement: Decentralised Application of EC Competition Law by National Courts (Hart, Oxford and Portland, Oregon 2008).

${ }^{4}$ They stated in footnote 16: "Although injunctions other than structural relief often accompany court decisions in antitrust cases, such measures cannot be considered to be in the same category as the antitrust penalties. Injunctions to prevent and restrain antitrust violations can take many forms. For example, they might bar an antitrust violator from making future acquisitions, require that a certain percentage of his output be sold to small independent firms, or establish detailed credit arrangements for the sale of commodities covered by the court order. The possible injunctions are limitless, and each would have to be analyzed on its own merits. But since our analysis is not concerned with the benchmarks by which to appraise the anticompetitive or procompetitive implications of various antitrust decisions, we have self-consciously omitted injunctions other than structural relief. [...]" Kenneth G Elzinga and William Breit, The Antitrust Penalties: A Study in Law and Economics (Yale University Press, New Haven 1977) 16.

${ }^{5}$ Barry J Rodger, 'Competition Law Litigation in the UK Courts, A Study of All Cases to 2004: Part 1' (2006) 27 European Competition Law Review 241-248; Barry J Rodger, 'Competition Law Litigation in the UK Courts: A Study of all Cases 2005-2008, Part I' (2009) 2 Global Competition Litigation Review 93-114. 
Table 1: Number of antirust injunctive relief in Germany and England and Wales

\begin{tabular}{clcc}
\hline & & \multicolumn{2}{c}{ Number of cases } \\
& & Germany & England and Wales ${ }^{+\dagger}$ \\
& & 2005 to 2007 & Up to 2008 \\
Primarily & Permanent injunctive relief & $105+$ & 2 \\
requested & Interim injunctive relief & 50 & 17 \\
remedy & Other types of relief* & 213 & 94 \\
& Total & 368 & 113 \\
\hline
\end{tabular}

\begin{abstract}
*Includes missing values.
tIncludes requests for the continuation or conclusion of a contract although these types of actions are sometimes regarded as damages actions.

†+ Data based on Rodger's studies and own research. Some cases may have been counted twice.
\end{abstract}

Even though the differing empirical findings on their own already justify a comparison between England and Wales and Germany, there are further arguments in favour of this particular comparison. England and Germany are the main proponents of two different legal systems. The former is usually referred to as a common-law jurisdiction while the latter belongs to the German civil law system. ${ }^{6}$ Thus, we do not only compare two jurisdictions in which the number of observed trials differ considerably but also two different legal systems that both belong to the European Union. It is sometimes claimed that property rights and contracts are better protected in common law countries which allegedly provide for a more efficient jurisdictional system. ${ }^{7}$ Both countries are major Member States with respect to their population and economic strength but they are also major (public) enforcers of competition law. These are good reasons why a comparison of an antitrust remedy, that did not receive much attention in the past, is not only justified but also needed. $^{8}$

\footnotetext{
${ }^{6}$ For the distinction of different legal systems see Konrad Zweigert and Hein Kötz, Introduction to Comparative Law ( $3^{\text {rd }}$ edn Clarendon Press; Oxford University Press, Oxford, New York 1998) 63; Rafael La Porta, Florencio Lopez-de-Silanes and Andrei Shleifer, 'The Economic Consequences of Legal Origins' (2008) 46 Journal of Economic Literature 285. Although one can distinguish common law and German civil law systems Zweigert and Kötz believe they are gradually moving closer together. Zweigert and Kötz ( $n$ 7) 271.

${ }^{7}$ La Porta, Lopez-de-Silanes and Shleifer (n 7) 286. Although La Porta's hypothesis is sufficient to justify more comparative work I will only discuss this point briefly in subsection $F$.

${ }^{8}$ Gerber's observations have also inspired this comparison. Gerber observed that Germany has got a long and rich tradition of comparative competition law which is often only available in German making it inaccessible for most foreign writers while. In contrast, the modernised and new UK competition law has become increasingly interesting from a comparative point of view. David J Gerber, 'Comparative Antitrust Law' in Mathias Reimann
} 
In the next subsections, I will look at the conditions that must be met to obtain injunctive relief in Germany and England and Wales and the function injunctions have in the respective legal system. A comparison of the legal tests will show that the differing prerequisites for injunctive relief may be one of the reasons for the varying usage of injunctive relief in England and Germany. In the first part of the paper, I will classify injunctions in a simple framework and briefly clarify concepts and terminology (section B). Subsection C is devoted to European law and the potential guidance that can be derived thereof regarding the availability and conditions for the grant of injunctions in private law suits. Part D explains injunctive relief in Germany and part E assesses the English case law. In the subsequent subsection $\mathrm{F}$ the findings will be summarised and compared. Part $\mathrm{G}$ concludes.

\section{B. Types of injunctions}

Injunctive relief is a very broad concept and may be understood differently across jurisdictions. In this part I will clarify the use of the terminology in this paper. I will also offer a classification of injunctions that is to guide my analysis. In very general terms one can think of an injunction as a court order which requests the defendant to undertake a certain action or to refrain from a certain action in order to protect the plaintiff's rights, prevent wrongful acts or undo a wrong. ${ }^{9}$ It is an authoritative official (re)statement of a duty owed by the defendant. Especially in common law jurisdictions injunctions can be referred to differently, for instance, as a specific performance in a contract context. ${ }^{10}$

Comparing injunctions, I will juxtapose a specific type of action that is made available for the violation of an individual right in two different jurisdictions, namely England and Wales and Germany. ${ }^{11}$ The common law concept is that of a remedy ${ }^{12}$ - which does not have one unified notion itself - while the violation of law in the German system provides for a claim. ${ }^{13}$ The term remedy

and Reinhard Zimmermann (eds), The Oxford Handbook of Comparative Law (Oxford University Press, Oxford 2006) 1193, 1212. Gerber also said that "[...] with notable exceptions, comparative analysis of competition law remains generally limited, superficial, and distorted." ibid 1194.

${ }^{9}$ This is a standard textbook definition. Simon F Deakin, Angus C Johnston and B. S Markesinis, Markesinis and Deakin's Tort Law (6th ed. Oxford University Press, Oxford 2008); Philip Cooke, Law of Tort ( $9^{\text {th }}$ edn Pearson Longman, Harlow, New York 2009).

${ }^{10}$ Rafal Zakrzewski, Remedies Reclassified (Oxford University Press, Oxford 2005) 121.

${ }^{11}$ The comparison of injunctions refers to the laws of Germany and England and Wales. I will not refer to Scot's law.

12 ibid.

${ }^{13}$ See section 194 of the German Civil Code. See also the use of language in Zweigert and Kötz ( $n$ 7) 595. 
refers to the instrument with which a right, stemming from a violation, can be enforced. ${ }^{14}$ In the German terminology an infringement of a law provision gives the victim a claim according to which he can ask the other party to do or not to do something. ${ }^{15}$ Such claim can then be enforced before the court if the plaintiff initiates the appropriate action like an action for performance or declaratory action. For the purpose of this paper, I will resort to injunctive relief in a broad sense including the meaning of remedy and claim. What is important to my comparison is the function of injunctive relief: how to request the defendant to (un)do or not to do something irrespective of the terminology or concepts used in the respective jurisdiction. ${ }^{16}$ Consequently, my analysis will address both procedural and substantive questions of law. Theoretically, one could distinguish the right from the remedy and the remedy from the procedural rules that govern the remedy, ${ }^{17}$ however, this distinction is blurred. For instance, the European Court of Justice (ECJ) established that compensation must be effectively available for antitrust violations. ${ }^{18}$ Confirming that there is an individual right stemming from Articles 101 and 102, the Court also implicitly required a national remedy to enforce the right. For the purpose of this paper, I will not distinguish between rights, remedies and procedure. The main aim is to show how the courts can order the defendant to do or not to do something (injunctions). I will look at how injunctions function and are utilised in England and Germany. I will focus on the question whether or not an injunction remedy is available and the conditions that must be met to obtain injunctive relief.

Injunctions can be categorised referring to the period of time they are awarded for, the character of the order and the content of the remedy. This is not a doctrinal systematisation of remedies as it has

\footnotetext{
${ }^{14}$ Dennis Solomon, Der Bereicherungsausgleich in Anweisungsfällen: Rechtsvergleichende Untersuchung zum deutschen Recht und zu den Rechtsordnungen des Common Law (Mohr Siebeck, Tübingen 2004) 133.

${ }^{15}$ See section 194 of the German Civil Code.

${ }^{16}$ Functionality is described as the main methodology of comparative law: "The question to which any comparative study is devoted must be posed in purely functional terms; the problem must be stated without any reference to the concepts of one's own legal system." Zweigert and Kötz (n 7) 34.

${ }^{17}$ Van Gerven phrased this nicely: "Although it is a "mission impossible" to define the concepts of ("subjective") rights, remedies and procedures (the latter two being brought normally under the broader concept of "procedural rules"), I must nevertheless propose a tentative definition for the sake of this article. The concept of right refers, in my view, to a legal position which a person recognized as such by the law - thus a legal "subject" (hence the name "subjective" right) - may have and which in its normal state can be enforced by that person against (some or all) others before a court of law by means of one or more remedies, those are classes of action, intended to make good infringements of the rights concerned, in accordance with the procedure governing the exercise of such classes of action and intended to make the remedy concerned operational. [...I]t is often difficult to distinguish between remedies and procedure (or remedial and procedural rules)." Walter van Gerven, 'Of Rights, Remedies and Procedure' (2000) 37 CMLR 501-536, 502.

${ }^{18}$ European Court of Justice, C-295/04 Manfredi v Lloyd Adriatico Assicurazioni SpA [2006] ECR I-6619.
} 
been undertaken, for instance, by Lawson, Burrows or Zakrazweski for the English law. ${ }^{19} \mathrm{My}$ classification provides nothing more than a starting point for the analysis to follow. As explained above, the guiding idea is to determine the types of injunctions that are available to claimants if EU or national competition law was violated and the legal requirements to obtain a certain type of injunction.

Injunctions can be granted with a permanent effect or for a limited period of time.$^{20}$ The former is referred to as a permanent or perpetual and the latter as a preliminary or interim injunction. ${ }^{21} \mathrm{~A}$ preliminary injunction preserves the status quo, or if the status quo harms the applicant, creates a transient state of matters which prevents irreparable or recurrent harm. A preliminary or interim injunction also enables the court to still make a decision on the merits that has some effect. Cumming defined an interim injunction as a "[...] provisional order granted by a court to an applicant who seeks to protect a legal enforceable right either from actual or apprehended infringement by the defendant prior to a full judicial determination of the matter by means of a full trial."22 If, for instance, the plaintiff runs the risk of bankruptcy if not further supplied by the defendant, the final decision will become redundant had the plaintiff to give up the business before the dispute is resolved. Naturally, a hearing on an interim remedy does not allow a full assessment of all facts and evidence. ${ }^{23}$ It is in the nature of a preliminary injunction that the decision includes some degree of uncertainty and a rather imprecise and cursory assessment. Although the standards for granting interim relief differ, courts have developed tests to exclude hopeless claims. For example, courts can test the chances of success of the plaintiff's assertion against the defendant's chance of fending off the claim or whether a serious issue is to be tried. In Germany the court normally assesses whether or not the applicant's case is coherent. ${ }^{24}$ As a general rule, no final decision on the merits is made in interim proceedings although it may have the effect sometimes. In contrast to interim relief, a permanent injunction comprises of a decision on the merits such as finally establishing a duty to licence or to grant access to a network.

\footnotetext{
${ }^{19}$ F. H Lawson and Harvey Teff, Remedies of English Law ( $2^{\text {nd }}$ edn Butterworth, London 1980); Andrew S Burrows, Remedies for Torts and Breach of Contract ( $3^{\text {rd }}$ edn Oxford University Press, Oxford 2004); Zakrzewski (n 11).

${ }^{20}$ Steven Gee, Commercial Injunctions $\left(5^{\text {th }}\right.$ edn Sweet \& Maxwell, London 2004) 2.002; David Bean, Injunctions $\left(9^{\text {th }}\right.$ edn Sweet \& Maxwell, London 2007) 1.01.

${ }^{21}$ John S Hodgson and John Lewthwaite, Tort Law: Textbook ( $2^{\text {nd }}$ edn Oxford University Press, Oxford 2007) 462.

${ }^{22}$ Bean (n 21) 1.01; George Cumming, Brad Spitz and Ruth Janal, Civil Procedure Used for Enforcement of EC Competition Law by the English, French and German Civil Courts (Kluwer Law International, Alphen aan den Rijn 2007) 159. See also the definition in section 935 German Civil Procedure Code.

${ }^{23}$ Bean (n 21) 1.01.

${ }^{24}$ Section 935 German Civil Procedure Code.
} 
Another distinction can be made with regards to the character of injunctions. The simplest case is a request ordering the defendant to stop the anticompetitive conduct; that is not to do a certain act. This type of injunction is also referred to as a prohibitory or negative injunction. ${ }^{25}$ The defendant can comply with this injunction by 'doing nothing'. Such an injunction replicates a negative right to forbear from doing an act or a positive right which correlates with a duty on the other party to do an act. ${ }^{26}$ If the request goes beyond the prohibition of a specific behaviour, the plaintiff asks for a mandatory injunction. Mandatory injunctions are orders in which the judge demands the defendant to do or undo something. ${ }^{27}$ Complying with such a court order requires the defendant to do some positive act. ${ }^{28}$ Where harm has been done, a prohibitory injunction may be issued with reference to the future, ordering the defendant to cease carrying on the activity. But the harmed individual may also ask for a mandatory injunction ordering the defendant to put matters right. The latter injunction goes beyond a simple prohibition as it also imposes a duty to act on the defendant. ${ }^{29}$ With mandatory injunctive relief the applicant can seek access to networks or an essential facility at a reasonable price or fair conditions, a rather typical injunction case under Article 102. Litigants can also force the defendant to continue a contract (in case of a refusal to further supply) or even to enter into an agreement in the first place. ${ }^{30}$ Both mandatory and prohibitory injunctions can, theoretically, be granted on a preliminary or permanent basis.

Having differentiated between the time period for which injunctive relief can be requested and the character of injunctions, another potential criterion to classify relief is the actual content of the order or, to be more precise, the competition law statute that underpins the plaintiff's claim. On a very simple scale anticompetitive conduct can fall into three groups: violations of Article 101 or the national equivalent; that is anticompetitive horizontal or vertical agreements, breaches of Article 102; that is unilateral conduct, or infringements of the merger regulations. ${ }^{31}$ If the defendant was found to have violated Article 102 offering discriminating conditions or an unfair price, the victim may request the defendant to either stop the discrimination (prohibitory injunction) or to grant him access to the products or input to non-discriminatory conditions (mandatory injunction). But also violations that fall under Article 101 or the merger control regime could be subject to interim or

\footnotetext{
${ }^{25}$ Gee (n 21) 2.002; Hodgson and Lewthwaite (n 22) 462.

${ }^{26}$ Zakrzewski (n 11) 122.

${ }^{27}$ Lawson and Teff (n 20) 177.

${ }^{28}$ Gee (n 21) 2.002.

${ }^{29}$ Deakin, Johnston and Markesinis (n 10) 1031.

${ }^{30}$ Komninos (n 4) 215.

${ }^{31}$ EC Merger Regulation 139/2004, OJ [2004] L24/1 (ECMR); Part 3 of the Enterprise Act 2002, sections 35 Act Against Restraints of Competition (ARC).
} 
permanent injunctions. Refining this classification, one could even distinguish between injunctions against cartels, vertical restraints, exclusive and exploitative abuse of dominance, and mergers.

A last point that has gained importance, especially in the US, is the relationship between injunctions based on contract disputes and applications that are brought for the violation of competition law. ${ }^{32}$ If special claim-motivating rules exist for antitrust litigation, parties of a contract dispute are probably inclined to look for an antitrust hook in their case in order to benefit from facilitated access to courts or evidence. Currently, most European jurisdictions do not provide for multiple antitrust damages awards or far-reaching antitrust discovery. The relationship between contract and antitrust cases is not a major issue yet, but it may well become a problem in the future if special rules for antitrust remedies were to be introduced in Europe. For this reason, I will look at the use of antitrust injunctions in a contract context.

The classification of injunctions outlined above serves as a guidance to compare the grant and denial of injunctions before English and German courts. Before the analysis of German and UK case law, the next subsection will survey the European law for principles governing remedies available in disputes between private parties for the violation of the European antitrust rules.

\section{Injunctions and European law}

In this section I will describe the European principles that guide the availability of injunctions for private parties in court proceedings based on the violation of EU antitrust law. For the most part, I will not discuss the power of competition authorities to grant injunctive relief or the powers of the courts to order injunctive relief in public-private proceedings. Similarly, I excluded most of the literature and discussion on the principle of effectiveness, especially when it dealt with public private relationships and disputes that were based on the failure of governments to meet obligations from the Treaty. ${ }^{33}$ This section will look at the guidance that has been given by the European courts towards the availability of injunctive relief in private antitrust proceedings.

\footnotetext{
${ }^{32}$ William J Baumol and Janusz A Ordover, 'Use of Antitrust to Subvert Competition' (1985) 28 Journal of Law \& Economics 247-266; A. M Polinsky and Daniel L Rubinfeld, 'Sanctioning Frivolous Suits: An Economic Analysis' (1993) 82 Georgetown Law Journal 397-435; Herbert Hovenkamp, The Antitrust Enterprise: Principle and Execution (Harvard University Press, Cambridge, Mass. 2005).

${ }^{33}$ For an extensive analysis see, for instance, Angela Ward, Judicial Review and the Rights of Private Parties in EU Law ( $2^{\text {nd }}$ edn Oxford University Press, Oxford 2007).
} 
In the absence of Community rules governing a certain matter it is in the powers of the Member States to set up the procedural rules and the remedies for violations of European law. ${ }^{34}$ The European courts do not have jurisdictions over individual applications for injunctive relief. ${ }^{35}$ It is a matter that is dealt with in the courts of the Member States. Notwithstanding the procedural autonomy of the Member States, the ECJ ruled on the availability of damages actions to plaintiffs in antitrust proceedings in the Courage and Manfredi cases. ${ }^{36}$ While the Court ruled on the availability of damages between private parties on two occasions, there have not been preliminary references to the court directly related to the availability of permanent injunctive relief in disputes between private individuals for the violation of the EU antitrust rules. There have been cases, however, in which the ECJ was faced with the question of whether or not national courts should grant interim injunctions against public acts like, for instance, in the seminal Factortame case. ${ }^{37}$

It has long been established that the European antitrust provisions have direct effect. ${ }^{38}$ The provisions laid out in Articles 101 and 102 confer rights directly to individuals. The consequences of a violation of those rights are, apart from the nullity order for anticompetitive agreements in Article 101(2), governed by the laws of the national states. The Member States set up the remedies, the procedural framework and determine the courts. ${ }^{39}$ Although in principle the Member States have free reign to regulate the consequences of a breach of European law, they are restrained by the principles of effectiveness and equivalence. The principle of equivalence requires that for actions which are based on Community law, the conditions as to both the substance and the form laid down by the various national laws may not be less favourable than those relating to similar domestic claims. ${ }^{40}$ Therefore, it should not make a difference if a victim decides to seek a remedy based on a violation of Article 102 or on the basis of the German or English equivalent. According to the principle of effectiveness, Member States have to ensure that the conditions for remedies are not

\footnotetext{
${ }^{34}$ European Court of Justice, C-453/99 Courage Limited v Bernard Crehan [2001] ECR I-06297 para 29; Manfredi v Lloyd Adriatico Assicurazioni SpA (n 18) para 62.

${ }^{35}$ See Articles $251 \mathrm{f}$. TFEU about the jurisdiction of the Court of Justice.

${ }^{36}$ Courage Limited v Bernard Crehan (n 35); Manfredi v Lloyd Adriatico Assicurazioni SpA (n 19).

${ }^{37}$ European Court of Justice, C-213/89 R. v Secretary of State for Transport Ex p. Factortame Ltd [1990] ECR I2433; Ward (n 34). See also European Court of Justice, Case 33/76 Rewe Zentralfinanz eG v Landwirtschaftskammer fur das Saarland [1976] ECR 1989; Peter Oliver, 'Interim Measures: Some Recent Developments' (1992) 29 CMLR 7-27.

${ }^{38}$ European Court of Justice, 127/73 Belgische Radio en Televisie v SABAM SV (No.2) [1974] ECR 313; European Court of Justice, C-234/89 Delimitis v Henninger Brau AG [1991] ECR I-935.

${ }^{39}$ Belgische Radio en Televisie v SABAM SV (No.2) (n 39); Rewe Zentralfinanz eG v Landwirtschaftskammer fur das Saarland (n 38); Delimitis v Henninger Brau AG (n 39); Courage Limited v Bernard Crehan (n 35); Manfredi v Lloyd Adriatico Assicurazioni SpA (n 19).

${ }^{40}$ European Court of Justice, 199/82 Amministrazione delle Finanze dello Stato v San Giorgio SpA [1983] ECR 3595; European Court of Justice, C-479/93 Francovich v Italy [1995] ECR I-03843; Courage Limited v Bernard Crehan (n 35).
} 
framed in a way as to render it virtually impossible or overly difficult to exercise the rights that were conferred by European law. ${ }^{41}$ In the abovementioned Courage and Manfredi rulings the court confirmed the availability of damages claims in national courts for a violation of Articles 101 and 102 on the basis of the effectiveness doctrine.

The principles of effectiveness and equivalence order the national courts to award damages for the violation of the EU antitrust statutes. Provided that a national legal system arranges for injunctions for violations of national competition law, the same must apply when EU antitrust rules are breached. Whether the principle of effectiveness requires injunctive relief for the violation of EU competition law if the law of a Member State does not permit, or only in limited circumstances allows, the use of injunctive relief for breaches of national statutory provisions is a different matter. European law does not give an answer to this problem but the strong stance the ECJ took in Courage and Manfredi may suggest that injunctions could be available with a similar rationale: ${ }^{42}$

"In the absence of Community rules governing the matter, it is for the domestic legal system of each Member State to designate the courts and tribunals having jurisdiction and to lay down the detailed procedural rules governing actions for safeguarding rights which individuals derive directly from Community law, provided that such rules are not less favourable than those governing similar domestic actions (principle of equivalence) and that they do not render practically impossible or excessively difficult the exercise of rights conferred by Community law (principle of effectiveness) [...]." ${ }^{43}$

Applying this rational, one could argue that the national courts should not reject an application for injunctive relief based on the infringement of Articles 101 or 102 if the denial would make it particularly difficult for the victim to enforce his rights. Instead, the injunction ought to be granted according to the principle of effectiveness to safeguard the directly applicable EU rights.

Although no direct statement of the courts with respect to perpetual private antitrust injunctions exists, a few procedures were based on injunctions or evolved from related questions. In Automec, an action for annulment against a decision of the European Commission, the applicant prompted the Court of First Instance (CFI, now the General Court) to deal with the Commission's powers to order a specific injunction. Automec, an Italian motor car distributor whose contract with BMW was not renewed, sought an order from an Italian court stating that the previous contractual relations are to be continued. The claim was dismissed. The Commission refused Automec's request to order BMW to comply with Automec's application or to admit Automec to BMW's selective distribution system.

\footnotetext{
${ }^{41}$ Courage Limited v Bernard Crehan (n 35).

${ }^{42}$ Courage Limited v Bernard Crehan (n 35); Manfredi v Lloyd Adriatico Assicurazioni SpA (n 19).

${ }^{43}$ Manfredi v Lloyd Adriatico Assicurazioni SpA (n 19) para 62.
} 
Automec then sought the annulment of the Commission's decision before the CFI. The CFI struck down Automec's case. As for the consequences of a breach of Article 85 EC (now Article 101 TFEU), the court stated:

"Article 85(1) prohibits certain anti-competitive agreements or practices. Among the consequences which an infringement of that prohibition may have in civil law, only one is expressly provided for in Article 85(2), namely the nullity of the agreement. The other consequences attaching to an infringement of Article 85 of the Treaty, such as the obligation to make good the damage caused to a third party or a possible obligation to enter into a contract [...] are to be determined under national law. Consequently, it is the national courts which, where appropriate, may, in accordance with the rules of national law, order one trader to enter into a contract with another." 44

Although this is a case in which the applicant requested the European Commission to order an injunction, a public rather than a private remedy, the court acknowledged inter alia that a violation of the EU antitrust rules triggers more than just voidness provided for in Article 101(2). The judges pointed out that damages ("obligation to make good the damage") and injunctions ("possible obligation to enter into a contract") can be civil law consequences of an antitrust violation. Notwithstanding the assertion that the freedom of contract remains the rule, the court affirmed the availability of injunctions in the context of antitrust law. At the same time, it made clear that injunctions are to be awarded under national law to the conditions laid out in national substantive and procedural rules. The court did not apply the principle of effectiveness as the question was not whether an injunction would be available under national law but whether the Commission can order a positive injunction. The court also refrained from issuing an opinion with regards to Article 102.

Although the CFI did not specify the available types of injunctions, the statement of the Advocate General Edward in Automec as for the character of injunctive relief implies that plaintiffs can seek more than just a prohibitory injunction. He characterised Automec's request as a "positive injunction" although only in the context of the Commission's (non-existing) powers to grant such an injunction. ${ }^{45}$ Since Automec requested the Commission to do something, this positive injunction was a claim for mandatory injunctive relief. In the absence of a final ruling (on a preliminary reference) but with regards to the stance the ECJ took on injunctive relief in Automec, one could argue that EU law requires the existence and provision of prohibitory or mandatory permanent injunctions in the laws of the Member States. ${ }^{46}$

\footnotetext{
${ }^{44}$ Court of First Instance, T-24/90 Automec Srl v Commission of the European Communities [1992] ECR II-2223 para 50. (emphasis added).

${ }^{45}$ For the Commission's powers see Articles 17 of the Modernisation Regulation, 1/2003 OJ 2003 L1/1.

${ }^{46}$ Another point that arises from Automec is the court's emphasis on the complementary function of private enforcement. It was stressed that the European Commission did not and does not have the powers to order,
} 
Although there is little direct guidance with respect to permanent injunctions, notwithstanding the principle of effectiveness and equivalence, there have been preliminary rulings based on private antitrust claims for injunctive relief. A prominent example is the ECJ's decision in Oscar Bronner. The Bronner ruling was handed down after a reference from the Austrian Higher Regional Court of Vienna. The Austrian court was asked to order the defendant to stop abusing its dominant position. ${ }^{47}$ The ECJ did not deal with the remedy as the Austrian court only asked questions related to the abuse of dominance. In another abuse case, Kanal 5 Ltd v Foreningen Svenska Tonsattares Internationella Musikbyra (STIM) upa, the ECJ ruled on a preliminary reference made by a Swedish court. $^{48}$ The applicants before the Swedish court had sought an injunction to prevent the respondent, an association which collected royalties for composers and music publishers, from abusing its dominant position. These cases exemplify that injunctions were used in different jurisdictions to enforce perceived breaches of Article 102 or violations of intellectual property rights. It is usually the victim of unilateral conduct that seeks an injunction against the infringer although there are cases in which the dominant undertaking requests a court order to stop a violation of, for instance, its property rights like in IMS Health. ${ }^{49}$

Some vague guidance as for the availability of interim relief in private antitrust proceedings is offered by the Factortame decision of the ECJ. ${ }^{50}$ In a preliminary reference, the House of Lords raised the question whether, notwithstanding a rule of a national law, English courts had the power under Community law, to grant an interim injunction against the Crown. The ECJ held that the effectiveness of the Community law would be impaired if a national rule prevents a nation court from granting interim relief in a dispute governed by European law. If such a national statute exists, it must be set aside. ${ }^{51}$ Although this case did not deal with a dispute between two private parties, but the argument between the Secretary of State and Factortame, it is nevertheless a strong indicator for the importance and availability of interim injunctive relief when the effectiveness of

\footnotetext{
for instance, the conclusion of a contract (injunction). If, for example, a refusal to deal violates Article 102, it is up to the victim to enforce the conclusion of a contract before a national court. In my reading, this shows that private actions are supplementing public enforcement, especially in the area of contract related litigation.

${ }^{47}$ European Court of Justice, Case C-7/97 Oscar Bronner GmbH \& Co KG v Mediaprint Zeitungs- und Zeitschriftenverlag GmbH \& Co KG [1998] ECR I-7791.

${ }^{48}$ European Court of Justice, C-52/07 Kanal 5 Ltd v Foreningen Svenska Tonsattares Internationella Musikbyra (STIM) upa [2008] ECR I-9275.

${ }^{49}$ European Court of Justice, Case C-418/01 IMS Health GmbH \& Co OHG v NDC Health GmbH \& Co KG [2004] ECR I-5039.

${ }^{50}$ R. v Secretary of State for Transport Ex p. Factortame Ltd (n 38).

${ }^{51}$ ibid para 21.
} 
European law is concerned. ${ }^{52}$ The Advocate General Tesauro in his thorough analysis of interim injunctions stressed the importance of such a preliminary measure:

"Interim protection has precisely that objective purpose, namely to ensure that the time needed to establish the existence of the right does not in the end have the effect of irremediably depriving the right of substance, by eliminating any possibility of exercising it; in brief, the purpose of interim protection is to achieve that fundamental objective of every legal system, the effectiveness of judicial protection. Interim protection is intended to prevent so far as possible the damage occasioned by the fact that the establishment and the existence of the right are not fully contemporaneous from prejudicing the effectiveness and the very purpose of establishing the right, which was also specifically affirmed by the Court when it linked interim protection to a requirement that, when delivered, the judgment will be fully effective; or to the need to 'preserve the existence position pending a decision on the substance of the case.' "153

Since both the ECJ and the Advocate General stressed the importance of the effectiveness doctrine, the arguments point towards a generally available interim relief in private proceedings based on European law. According to Papadias, the Court of Justice did not directly determine the Community legal basis for such interim jurisdiction or under which circumstances a national court may grant interim relief. ${ }^{54}$ However, the European Court of Justice refined and reaffirmed its position in the more recent Unibet decision although the dispute also ensued from the question of compatibility of national law with Community law. ${ }^{55}$ It was reasoned that national rules are inapplicable which impose a total ban on preliminary measures. ${ }^{56}$ Provided that interim measures are required for private proceedings involving Community law in order to ensure the effective application thereof, both rulings kept silent on the extent of interim relief. This is to be governed by the national states. As both England and Germany principally provide for interim injunctions in private antitrust proceedings, it is less a question of whether or not interim relief is available but to what extent it must be made available. The principle of effectiveness only requires that national rules do not render practically impossible or excessively difficult the exercise of rights conferred by Community law. This is still a very vague standard to govern the availability of interim relief in the states.

\footnotetext{
${ }^{52}$ For a discussion of Factortame Lambros Papadias, 'Interim Protection under Community Law before the National Courts - The Right to a Judge with Jurisdiction to Grant Interim Relief' (1994) 21 Legal Issues of European Integration 153-193; Ward (n 34), 96; Georgios Anagnostaras, 'The Incomplete State of Community Harmonisation in the Provision of Interim Protection by the National Courts' (2008) 33 European Law Review 586-597.

${ }^{53}$ R. v Secretary of State for Transport Ex p. Factortame Ltd (n 38) para 18.

${ }^{54}$ Papadias (n 53) 175.

${ }^{55}$ European Court of Justice Unibet (London) Ltd and Unibet (International) Ltd v Justitiekanslern [2007] ECR I2271. For comments see Xavier Groussot, Wenander and Henrik, 'Self-standing Actions for Judicial Review and the Swedish Factortame, Case comment' (2007) 26 Civil Justice Quarterly 376-388. For an overview about interim proceedings provided for in national courts see Anagnostaras ( $n 53$ ).

${ }^{56}$ ibid 590.
} 
In contrast to the private damages remedy, which have been expressively confirmed by the ECJ, the same cannot be said about injunctive relief. Neither permanent nor preliminary injunctions in private litigation have been asserted by the ECJ yet. However, there is strong case for the availability of permanent and interim injunctive relief in private antitrust proceedings in the national states. Requiring the Member States to provide for a damages remedy for the violation of competition rules in Courage and Manfredi, the Court of Justice set out more general guidance as to the availability of remedies. ${ }^{57}$ Applying the effectiveness doctrine as laid out in these judgements, one could argue that a similar rational requires effective injunctive relief for violations of EU competition law.

\section{Injunctions in German antitrust law}

Empirical research on German private antitrust cases has shown that the antitrust plaintiffs who seek relief before the German courts frequently resort to injunctions. ${ }^{58}$ The legislator also stressed the importance of injunctive relief and the right to removal placing it first in section 33 of the Act Against Restraints of Competition (ARC) which contains the remedies available for a breach of antitrust law. At the same time, the literature deals, more often than not, with antitrust damages actions. Numerous publications have explored the different aspects of compensation in the antitrust context in Germany. ${ }^{59}$ Emmerich believes that the reason for this selection bias is the absence of any

\footnotetext{
${ }^{57}$ Courage Limited v Bernard Crehan (n 35); Manfredi v Lloyd Adriatico Assicurazioni SpA (n 19).

${ }^{58}$ Sebastian Peyer, 'Myths and Untold Stories - Private Antitrust Enforcement in Germany'(CCP Working Paper 2010, SSRN e-library).

${ }^{59}$ Antitrust damages actions were explored, for instance, in Rolf Hempel, Privater Rechtsschutz im Kartellrecht: Eine rechtsvergleichende Analyse (Nomos, Baden-Baden 2002); Markus Röhrig, Schadensersatzansprüche im deutschen Kartellrecht nach der 6. GWB-Novelle: Eine ökonomische Betrachtung privater Wettbewerbsaufsicht am Beispiel des neuen Mißbrauchsverbots gemäß § 19 GWB (Lang, Frankfurt am Main 2004); Friedrich W Bulst, Schadensersatzansprüche der Marktgegenseite im Kartellrecht: Zur Schadensabwälzung nach deutschem, europäischem und US-amerikanischem Recht (Nomos, Baden-Baden 2006); André Görner, Die Anspruchsberechtigung der Marktbeteiligung nach § 33 GWB (Heymann, Köln 2007); Florian Endter, Schadensersatz nach Kartellverstoß: Eine rechtsvergleichende Untersuchung der Anspruchsgrundlagen im europäischen, deutschen und englischen Recht (Stämpfli, Bern 2007); Christina Kaufmann, Rechtsschutz im deutschen und europäischen Kartellrecht: Konzeption einer effektiven Schadensersatzklage (VDM Verlag Dr. Müller, Saarbrücken 2007); Moritz Votteler, Der Schadensersatzanspruch im EG-Kartellrecht: Existenz und Ausgestaltung (Kovac, Hamburg 2008); Hans-Wilhelm Krüger, Öffentliche und private Durchsetzung des Kartellverbots von Art. 81 EG: Eine rechtsökonomische Analyse (Deutscher Universitäts-Verlag | GWV Fachverlage GmbH Wiesbaden, Wiesbaden 2008); Hans P Logemann, Der kartellrechtliche Schadensersatz: Die zivilrechtliche Haftung bei Verstößen gegen das deutsche und europäische Kartellrecht nach Ergehen der VO (EG) Nr. 1/2003 und der 7. GWB-Novelle (Duncker \& Humblot, Berlin 2009); Jürgen Keßler, Schadensersatz und Verbandsklagerechte im Deutschen und Europäischen Kartellrecht: Gutachten im Auftrag des Verbraucherzentrale Bundesverbandes e.V (BWV Berliner Wiss.-Verl. Berlin 2009); Jan P Westhoff, Der Zugang zu Beweismitteln bei Schadensersatzklagen im Kartellrecht: Eine rechtsvergleichende Untersuchung (Nomos, Baden-Baden 2010); Peter Behrens, Schadensersatzklagen gegen Kartellmitglieder: Forum Wissenschaft und Praxis zum Internationalen Wirtschaftsrecht (Nomos, Baden-Baden 2010); Christian Alexander, Schadensersatz und Abschöpfung im Lauterkeits- und Kartellrecht (Mohr Siebeck, Tübingen 2010); Alexander Kruß,
} 
specific antitrust issue in injunctive relief requests. ${ }^{60}$ In this subsection, I will delineate the legal and factual circumstances in which injunctive relief is granted first dealing with the different types of permanent injunctions and then turning towards interim injunctive relief. ${ }^{61}$

\section{Perpetual injunctions}

Section 33(1) ARC provides for the remedies for breaches of the antitrust laws. It states that victims have, inter alia, an injunction or removal claim against the perpetrator if a provision of the ARC or European antitrust rules are violated or an order of the competition authority was breached. The law differentiates between claims to remove or remediate a disturbance (Beseitigungsanspruch) and a right to injunctions (Unterlassungsanspruch). ${ }^{62}$ Both claims are the consequences of a breach of an antitrust provision. Interestingly, it was not until the $6^{\text {th }}$ amendment of the ARC in 1999 that antitrust injunctions were explicitly regulated in the ARC. The claim to remove an infringement was included with the $7^{\text {th }}$ amendment in 2005. Nevertheless, the existence of these claims had not been in doubt before the changes of the competition law provisions took place. Prior to their inclusion in the ARC, claims for injunctive relief were based on the general principles of the German Civil Code. ${ }^{63}$ For instance, the German Civil Code provides for injunctions in sections 12 and 1004 to protect

Kartellschaden und Verbraucherschutz: Rechtliche und faktische Rechtsdurchsetzungshürden für die Kompensation kartellbedingter Streuschäden unter Berücksichtigung gemeinschaftsrechtlicher Vorgaben (Kovac, Hamburg 2010); Kay Wissenbach, Von der behördlichen Kartellrechtsdurchsetzung zum privaten Schadenersatzprozess (Universitätsverlag, Halle, Saale 2010); Carsten Krüger, Kartellregress: Der Gesamtschuldnerausgleich als Instrument der privaten Kartellrechtsdurchsetzung (Nomos, Baden-Baden 2010); Wernhard Möschel (ed), Kartellrechtsdurchsetzung durch private Schadenersatzklagen? (Nomos, Baden-Baden 2010).

${ }^{60}$ Volker Emmerich in Ulrich Immenga and Ernst-Joachim Mestmäcker (eds), GWB: Kommentar zum Deutschen Kartellrecht $\left(4^{\text {th }}\right.$ edn Beck, München 2007) § 33 para 9.

${ }^{61}$ It is sometimes difficult to fully assess German cases as only the very basic facts of the case are presented. As for this rather continental practice, Zweigert and Kötz have observed: "Above all, judgments of supreme courts on the Continent still sometimes reflect the traditions of the authoritarian state of a hundred years ago: judgments should primarily be impersonal acts of state which parade the majesty of the law in front of citizens in awe of authority; therefore they must not let it emerge that judges reach their decisions through a hesitant and doubtful balancing of the pros and cons of concrete solutions of the problem thrown up by the 'case', rather than by sheer intellect and cold logic. Another indication of how underdeveloped the art of 'reasoning from case to case' remains is the uncritical use made of the 'headnotes' (Leitsätze) which precede published judgements all over the Continent. These headnotes present a very brief and abstract version of the essential legal proposition basic to the court decision but they omit the underlying facts or only hint at them and never give the reasoning on which the decision was founded." Zweigert and Kötz (n 7) 264.

${ }^{62}$ See in general Alexander Fritzsche, 'Der Beseitigungsanspruch im Kartellrecht nach der 7. GWB-Novelle, Zugleich ein Beitrag zur Dogmatik des quasi-negatorischen Beseitigungsanspruchs' (2005) Wettbewerb in Recht und Praxis 42-54; Jörg Fritzsche, Unterlassungsanspruch und Unterlassungsklage (Springer, Berlin 2007).

${ }^{63}$ Wulf-Henning Roth in Helmut Glassen and others (eds), Frankfurter Kommentar zum Kartellrecht: Mit Kommentierung des GWB, des EG-Kartellrechts und einer Darstellung ausländischer Kartellrechtsordnungen (Schmidt, Köln 2000) § 33 para 171; Fritzsche (n 63) 44; Emmerich (n 61) para 90. 
individuals from a violation of their absolute rights. The protection of absolute (property) rights was extended to, among others, the individual rights created by the competition law provisions. Thus, the latest amendments of the ARC did not create these remedies but reaffirmed and expressively governed them. Section 33(1) ARC reads:

\begin{abstract}
"Whoever violates a provision of this Act, Articles 81 or 82 of the EC Treaty or a decision taken by the cartel authority shall be obliged to the person affected to remediate and, in case of danger of recurrence, to refrain from his conduct. A claim for injunction already exists if an infringement is foreseeable. Affected persons are competitors or other market participants impaired by the infringement." ${ }^{64}$
\end{abstract}

Obviously, section 33(1) ARC provides for two different types of remedies (claims): the remediation or removal of current and continuous harm and an injunction ordering the defendant to cease from further breaches of the antitrust provisions. Notwithstanding the distinction that can be made, it is not always adhered to by the courts. A court may well find that the defendant had violated an antitrust statute and force the perpetrator to stop the breach, for instance, on the basis of an "injunction and removal claim". ${ }^{65}$ Although both remedies fall into the overall category of injunctive relief, they differ with respect to their purpose.

Standing to bring permanent or temporary injunction requests have those who are affected by the violation of the antitrust provisions or will be affected by a future breach. ${ }^{66}$ The ARC refers to individuals being affected when they are competitors or customers of the perpetrator. Individuals have standing if their freedom of action is affected and, thus, their chances in the market are deteriorated. ${ }^{67}$ The condition of being affected replaced the old protective law requirement which was held to be too restrictive. The reading of "affected parties" is contentious nevertheless. Some claim that the law suggests a generally narrow reading of the affected party standard in damages actions. Because of this it must also be interpreted narrowly in removal and injunction claims. Those who support a narrow interpretation argue that the law does not provide for a differentiation between the different remedies as to the conditions under which they are awarded. ${ }^{68}$ Consequently, a restricted standing for damages actions must also apply to other remedies. Especially practicability,

\footnotetext{
${ }^{64}$ Translation by the German Federal Cartel Office.

${ }^{65}$ Bundesgerichtshof, KZR 2/58 Großhändlerverband (1959) 29 BGHZ 344; Fritzsche (n 63), 45.

${ }^{66}$ Eckard Rehbinder in Ulrich Loewenheim, Karl M Meessen and Alexander Riesenkampff (eds), Kartellrecht: Kommentar (Beck, München 2009) § 33 para 43.

67 ibid para 13.

${ }^{68}$ ibid para 16.
} 
efficiency of procedure and the opportunity to actually prove the loss argue in favour of a restrictive reading. On the other hand, the new standing requirement should be read against the ECJ's Courage decision demanding standing for every individual. ${ }^{69}$ In the absence of a final word from the Federal Court of Justice, the standing of parties for injunctions claims may become an issue if the plaintiff is remote the infringement.

\section{Injunction claims}

An injunction claim aims at stopping the illegal conduct for the future and does not repair past or actual harm. ${ }^{70}$ An injunction normally prohibits the further violation of the antitrust laws but, if the violation can only be remedied with some positive action, may amount to a positive command (mandatory injunction). In order to obtain an injunction, the plaintiff has to demonstrate that, first, the behaviour concerned violates a competition law provision or an order of the competition authority; second, the behaviour is unlawful and, third, there is a danger that a violation will occur (again).

The violation of the antitrust statutes includes infringements of European competition law, namely Articles 101 and 102, and breaches of the ARC. On equal terms with the competition law provisions are orders of the competition authority. The failure to obey with an order of the Federal Cartel Office can also trigger a claim for injunctive relief. Whether or not private parties can pursue a violation of the merger provisions with a private action is doubtful. The phrase "violates a provision of this Act" in section 33 ARC is rather broad and the provisions regulating merger control are part of the ARC. However, mergers are publicly controlled and it is generally thought that the merger provisions do not provide for an individual right of third parties that could be subject to private actions. Third parties that are potentially affected by a merger can participate in the public proceedings before the Federal Cartel Office. Those third party interventions are directed against the decision of the Federal Cartel Office and not directly against the merging parties. ${ }^{71}$ Whether or not competitors can seek an injunction in case the merging parties violate the orders of a conditional clearance, for instance, is not entirely clear. Again, as this order does not protect a private party it is unlikely that there is an individual right emanating from the order. Apart from the exclusion of

\footnotetext{
69 ibid para 8.

${ }^{70}$ Roth (n 64) para 178.

${ }^{71}$ See for more details: Torsten Körber, 'Gerichtlicher Drittschutz im deutschen Fusionskontrollrecht' (2000) 55 Betriebs-Berater (BB) 1532-1538; Ulrike Dormann, Drittklagen im Recht der Zusammenschlußkontrolle (Heymann, Köln 2000); Florian Bien, Fusionskontrolle und subjektiver Drittschutz (Nomos, Baden-Baden 2007).
} 
merger control, there are no restrictions as to the various types of anticompetitive behaviour that could be subject to injunctions.

In order to obtain an injunction the plaintiff must show that there is a danger that a violation will occur; that is the imminent infringement. ${ }^{72}$ If the defendant already violated the rights of the plaintiff, the danger that the breach of law is repeated indicates an imminent infringement. The risk of a reoccurring infringement is defined as a serious and real possibility that a violation is repeated. ${ }^{73}$ Normally, the plaintiff bears the burden of proof for the claim but if a violation has already happened, the risk of recurrence is presumed. It is then for the defendant to show that he will not further violate the plaintiff's rights. ${ }^{74}$ Section 33(1)2 ARC provides for a right of a potential victim to seek a court order against a foreseeable infringement. It is not necessary to await the occurrence of an antitrust breach in order to obtain an injunction. However, as there is no apparent harm yet, the bar to obtain a preventive injunction is set higher. The courts demand specific indications for an imminent detriment which must allow a credible legal assessment. ${ }^{75}$ In general, injunctions require the imminent danger of an infringement, which is particularly obvious if it is a repeated offense. But also the risk of a first-time violation creates the imminent danger which justifies an injunction. ${ }^{76}$ For both claims section 33(1) ARC does not require fault on part of the defendant. It is important to note that injunctions are awarded as of right similar to other remedies like damages. Injunctive relief is granted independently from other remedies. The adequacy of damages is not a criterion for the award of an injunction. Damages and injunctions are distinct remedies with different objectives.

It is difficult to give a complete overview of all instances in which plaintiffs asked for perpetual injunctions and removal in Germany. ${ }^{77}$ A careful estimate suggests that from 2004 to 2009 plaintiffs filed on average 200 private antitrust cases per year before German courts with most of these cases being injunctions or removal claims. ${ }^{78}$ My analysis is, therefore, limited, to some exemplary cases. In a number of cases injunction claims were used to forbid anticompetitive recommendations, a prohibition that was abolished with the $7^{\text {th }}$ amendment of the ARC. ${ }^{79}$ Before the changes in 2005,

\footnotetext{
${ }^{72}$ Emmerich (n 61) para 94.

${ }^{73}$ Rehbinder (n 67) para 42.

74 Bundesgerichtshof, KZR 20/78 Modellbauartikel II [1979] WuW/E BGH 1629 1632; Emmerich (n 61) para 96.

${ }^{75}$ Bundesgerichtshof, X ZR 41/90 Nicola [1992] NJW 2292, 2294; Roth (n 64) para 175.

${ }^{76}$ Joachim Bornkamm in Christian Bahr, Eugen Langen and Hermann-Josef Bunte (eds), Deutsches Kartellrecht $\left(10^{\text {th }}\right.$ edn Luchterhand, München 2006) $\S 33$ para 41.

77 Zweigert and Kötz noted that it is often difficult to extract more than the very basic facts from continental jurisprudence due to different legal traditions. Zweigert and Kötz (n 7) 264. I was faced with similar obstacles as the facts of some cases were not described in a very detailed manner.

${ }^{78}$ Peyer (n 59).

${ }^{79}$ See section 22 ARC as of 01 January 1999 (abolished).
} 
plaintiffs were able to enforce this statutory provision by means of injunction claims, for instance, against price recommendations or recommended goods. ${ }^{80}$ In a very recent case the customer of an electricity supplier asked the court to order the company to stop the alleged price discrimination. ${ }^{81} \mathrm{~A}$ mostly unsuccessful allegation of anticompetitive pricing was made in an injunction action filed by a taxi operator against a competing taxi cooperative. $^{82}$ In a claim against a dominant telecommunication service provider, a competitor alleging the abuse of dominance sought an injunction against the bundling of circuit-switched telephone networks and Internet access. ${ }^{83}$ Although injunctions against firms that abuse market power dominate, there have also been cases in which this remedy was sought in conjunction with selective distribution systems. ${ }^{84}$ In some instances, plaintiffs rephrased requests for delivery (duty to supply) so as to fit within an injunction claim. In one case the retailer of bags sought an injunction barring the manufacturer from imposing a ban on the plaintiff not to sell its bags on eBay. ${ }^{85}$ Acknowledging that the claim for an injunction also consists of a right to removal, the Federal Court of Justice granted access to a business association in one of its very early cases under the ARC. ${ }^{86}$

\section{Removal}

The second remedy that falls under the umbrella of injunctive relief is the removal claim, also provided for in section 33(1) ARC. Because of the overlapping content of the injunction and removal claims - both can impose a negative or positive duty on the defendant - it may be difficult to distinguish them. However, while injunctions aim at the future, removal claims are used to stop a current infringement. The conditions that must be met to obtain a removal claim do not differ significantly from those of an injunction. Since removal claims are aimed against current harm, they are not available if the intrusion into the rights is only threatening. The right to remove the violation requires an already existing and continued violation of an antitrust provision. Similar to the prerequisites for injunctions, there must be an illegal breach of antitrust law or the violation of an order of the competition authority. Fault is not a requirement for a successful removal action.

\footnotetext{
${ }^{80}$ Oberlandesgericht Koblenz, 6 U 1736/82 (Kart) Apothekenpreise [1984] GRUR 903; Oberlandesgericht Düsseldorf, U (Kart) 11/97 Positivliste [1997] NJWE-WettbR 263.

${ }^{81}$ Bundesgerichtshof, KZR 21/08, Entega [2009].

82 Bundesgerichtshof, KZR 12/86, Taxi-Preisgestaltung [1987] GRUR 926.

${ }^{83}$ Bundesgerichtshof, KZR 1/03, Der Oberhammer (2004) 158 BGHZ 334.

${ }^{84}$ Bundesgerichtshof, KZR 1/65, Pharmazeutische Großhandlung [1965] WuW/E BGH 759.

${ }^{85}$ Oberlandesgericht Karlsruhe, 6 U 47/08 Kart, Schulranzen [2009] GRUR-RR 109.

${ }^{86}$ Großhändlerverband ( $\mathrm{66}$ ). The access to business associations is now governed in section 20(6) ARC.
} 
The practical significance of the removal claims shows in instances of refusal to deal. ${ }^{87}$ If such a refusal violates Articles 101 or 102 or German competition law, the defendant may have a duty to supply. Whether or not the duty to supply stems from the removal claim or, as it was argued, is a consequence of the damages claim remains a contentious issues I will not comment on in detail. ${ }^{88}$ To separate damages claims, which offset harm done in the past, and removal claims, remedying current harm, it is said that the latter must be aimed at remedying a violation for the future as well. The aim is not to compensate the damage of the victim but to avoid the intrusion of rights for the future. ${ }^{89}$ Consequently, the claim for removal cannot be aimed at certain specified measure to eliminate past harm. Only damages claims can offset past losses. ${ }^{90}$ Some say that the removal of a source of nuisance is part of the damages claims and stems from the principle of restitution in kind. ${ }^{91}$ This should apply to access requests and actions aimed at the conclusion of agreements. Others argue that this is a typical case of a removal claim under section 33(1) ARC. In contrast to damages actions, removal and injunction requests do not require fault on part of the defendant. Fritzsche asserted that this fault requirement for damages claims separates compensatory actions from removal orders. ${ }^{92}$ Asking for compensation (damages) the plaintiff requests more than just the remediation of current harm. Pecuniary satisfaction for past harm requires fault as of principle while removal claims do not require fault. To ensure that there is sufficient difference between damages and removal claim, the condition of a "continuous infringement" must be satisfied too. ${ }^{93}$ To further obscure the distinction of removal and damages claims, courts have accepted removal actions aiming at the payment of money. In those cases, the continuous violation of the plaintiffs' right stemmed from the refusal to pay an appropriate commission or fee. ${ }^{94}$ This issues has not been ultimately decided yet although it seems that the Federal Court of Justice, which used to deal with obligations to supply or contract in the context of damages actions, ${ }^{95}$ passed over to the removal

\footnotetext{
${ }^{87}$ Emmerich (n 61) para 102.

${ }^{88}$ Helmut Köhler, 'Die wettbewerbsrechtlichen Unterlassungsansprüche (Unterlassung, Beseitigung, Widerruf)' (1992) NJW 137-143; Fritzsche (n 63); Fritzsche (n 63) 214.

${ }^{89}$ Großhändlerverband (n 66) 351.

${ }^{90}$ Fritzsche (n 63).

${ }^{91}$ Bornkamm (n 77).

92 Fritzsche (n 63), 44

${ }^{93}$ ibid.

94 Bornkamm ( $\mathrm{n} 77$ ) para 46. The plaintiff can request the payment of fair gratuity by means of a removal claim because it is the removal of a continuous intrusion in his rights. Bundesgerichtshof, Stromeinspeisung (1992) 119 BGHZ 335, 345; Bundesgerichtshof, KZR 31/95, Kraft-Wärme-Kopplung [1996] NJW 3005, 3006.

${ }_{95}$ Bundesgerichtshof, KZR 1/61, Gummistrümpfe [1961] NJW 196; Bundesgerichtshof, Depotkosmetik [1998] WuW/E DE-R 206. Not clear Bundesgerichtshof, KZR 15/86, Cartier-Uhren [1987] GRUR 327.
} 
claim for this purpose. ${ }^{96}$ More important for the antitrust plaintiff though is the fact that there are ways to counter an illegal refusal to deal.

Claims aimed at the removal of anticompetitive conduct have most importance in cases where the defendant refuses to deal with the plaintiff, where the plaintiff requests access to an essential facility according to section 19(4) No 4 ARC ${ }^{97}$ or instances of forced licensing. ${ }^{98}$ Injunctions were used in claims aimed at third party access to grids to transmit electricity, which also falls under section 19(4) No 4 ARC, and actions for admission to industry association according to section 20(6) ARC. ${ }^{99}$ Other examples of those requests are actions aimed at the repeal of unlawful recommendations, request for admission to lawful cartels and associations and actions to pay the appropriate fee in the case of discrimination of a supplier. ${ }^{100}$ Claims for delivery were successfully made with regard to draught beer and sport shoes. ${ }^{101} \mathrm{~A}$ manufacturer of high-end watches was ordered to permanently fulfil the warranty requests made for watches sold by the non-authorised plaintiff. ${ }^{102}$ Unsuccessful applications for delivery were made, for instance, by a retailer requesting the supply with designer furniture. In several decisions the court stressed that, despite an occasional duty to supply, it is generally in the freedom of the parties to organise their distribution system. ${ }^{103}$ Plaintiffs have also been unsuccessful in a case where the appeal on points of law to the Federal Court of Justice is still pending. The higher regional court denied an exclusive obligation to deliver in the newspaper wholesale market because, among other reasons, the plaintiff's claim was based on a faulty market definition. Whether or not the court dealt with the request for exclusive delivery as a damages claim or removal action is not clear from the judgement. ${ }^{104}$ The courts have also rejected the claim of a taxi operator that refused to sign the membership agreement for a centralised taxi call but sought the imparting of taxi calls to the same conditions as the members nevertheless. ${ }^{105}$ The removal and injunction claim based on allegations of unfair discrimination was struck down by the appeal court because the discrimination was both justified, as it took place between members and non-members of the cooperation, and not significant. As mentioned above, even pecuniary payments were based

\footnotetext{
${ }^{96}$ Stromeinspeisung (n 95); Bundesgerichtshof, KZR 5-94, Einspeisungsvergütung [1995] NJW-RR 1381; KraftWärme-Kopplung (n 95).

${ }^{97}$ Sections 19 and 20 ARC regulate the abuse of market power.

${ }^{98}$ Emmerich (n 61) para 102.

99 Pharmazeutische Großhandlung (n 85) 763; Roth (n 64) para 177.

100 Emmerich (n 61) para 102.

${ }^{101}$ Bundesgerichtshof, KZR 17/77, Faßbierpflegekette [1978] NJW 107; Bundesgerichtshof, KZR 19/80, adidas [1981] GRUR 917.

${ }^{102}$ Cartier-Uhren (n 96).

103 Depotkosmetik (n 96); Bundesgerichtshof, KZR 45/05, Lesezirkel II [2006] WuW/E DE-R 1832.

104 Oberlandesgericht Celle, 13 U 92/09 (Kart), Presse-Grosso-Vertrieb [2010] GRUR-RR 219.

105 Oberlandesgericht Naumburg, 1 U 13/08, Taxirufzentrale [2008] GRUR 114.
} 
on a removal claim because it was held that only the payment of the appropriate fee would remediate the current violation of the antitrust statute. ${ }^{106}$

The case law exemplifies that request to remove a current harm can go beyond the simple prohibition of illegal conduct. Plaintiffs may ask the defendant not to do something but are, within limits, also entitled to ask the defendant to do something. However, the courts have early pointed out that there are limits to the grant of mandatory injunctions. As of principle, it is left to the culprit how to remedy current and avoid future breaches of the law. This has been stressed by the Federal Court of Justice on several occasions. For example, when a firm with market power unfairly hinders or discriminates another firm according to section 20(1) ARC, the law allows for a claim for injunction or removal but does not provide for a right to request the perpetrator to carry out a certain action. ${ }^{107}$ Only where the violation can be remediated with one particular action, the court can order the defendant to undertake this specific action. ${ }^{108}$ In another case where the plaintiff demanded compulsory delivery from the defendant, the Federal Court of Justice stressed that the defendant has got the freedom to organise his business affairs as he sees fit. ${ }^{109}$ Typically, the defendant will have more than one option to address the finding of a breach of competition law. Instead of supplying the plaintiff, the defendant could reorganise its distribution system. Ultimately, the victim of anticompetitive conduct must be careful when demanding a mandatory court order.

Plaintiffs not only risk losing their case when they request one specific behaviour from the defendant despite there being alternative routes to comply with the competition laws; they must also phrase their application in such a way that the defendant knows what he is supposed to do. The rules of civil procedure demand that an application for a remedy has to be exact and precise about the content of the claim in accordance with section 253(1) No 2 Civil Procedure Code. ${ }^{110}$ The claim that is brought to court must be certain and precise in its definition. ${ }^{111}$ Thus, the claim for an injunction must be aimed at the precise infringement action of the defendant. An application of the plaintiffs seeking a performance of the defendant (to do something) can be unsuccessful if it is too broad. At the same time, a simple prohibitory injunction against discriminatory conduct (not to do something) could be

\footnotetext{
${ }^{106}$ Stromeinspeisung (n 95); Einspeisungsvergütung (n 97); Kraft-Wärme-Kopplung (n 95).

107 Bundesgerichtshof, KZR 21-04, Hinweis auf konkurrierende Schilderpräger [2005] WuW/E DE-R 1724 para 15.

108 ibid.

${ }^{109}$ Lesezirkel II (n 104) para 18.

${ }^{110}$ Oberlandesgericht Düsseldorf, 2 U (Kart.) 1/58, Mühlenkartell [1958] WuW/E OLG 230, 233.

${ }^{111}$ Bundesgerichtshof, ZR 35/89, Unbestimmter Unterlassungantrag [1990] NJW 1114, 1115.
} 
admissible. $^{112}$ If the defendant can choose from several options how to address an anticompetitive discrimination, the only appropriate action for the plaintiff is to request a prohibition of the illegal conduct. As the courts are reluctant to impose positive actions on the defendant, they require the plaintiff to be as precise as possible if they do so. For example, in disputes stemming from a refusal to deal the good that is to be delivered must be precisely stated. ${ }^{113}$

\section{Interim relief}

The types of injunctive relief described in the previous section are understood as a perpetual or permanent remedy being awarded after a full trial has been carried out. When time is of the essence a preliminary order can be, and normally is, sought by the plaintiff. In general, injunctive relief claims made on a permanent basis can also be subject to interim requests. As for interim relief, the general rules of the German Civil Procedure Code apply. Providing for interim claims, the law intends to safeguard the current state against changes rendering the enforcement of a right impossible or considerably more difficult. ${ }^{114}$ In order to obtain an interim injunction, the claimant must establish a coherent prima facie case and that the urgency of the decision is needed according to section 935 Civil Procedure Code. Section 940 of the Civil Procedure Code extends the temporary protection of the rights of the applicant providing for interim relief with regards to a legal relationship in dispute. Section 935 requires a claim (action for performance, action requesting a change of legal rights or status, or an action for declaratory judgement) which is to be secured. An injunction claim under the antitrust statutes is normally an action for a performance and represents a valid case if it is pleaded coherently and a prima facie case is established. It appears from the case law that the courts cursorily test the probability of success of the claimant's action. The onus of proof is distributed similarly to a full trial but with relaxed requirements regarding the evidence and the level of persuasion. ${ }^{115}$ Although there is no general rule as to the likelihood of winning, the success of the plaintiff in trial must be at least probable. Otherwise it would be difficult to vindicate a far-reaching interim measure. The potential disadvantages for both sides will be weighed and determine the level of evidence necessary. If the grant of an interim injunction will in all likelihood cause severe

\footnotetext{
${ }^{112}$ For procedural issues and the adjunctive problems of phrasing the application before court see Martin Schockenhoff, 'Die gerichtliche Durchsetzung von Belieferungsansprüchen aus § 26 II GWB' (1990) NJW 152158.

113 adidas ( $\mathrm{n}$ 102) 917.

${ }^{114}$ Ingo Drescher in Thomas Rauscher, Peter Wax and Joachim Wenzel (eds), Münchener Kommentar zur Zivilprozessordnung: Mit Gerichtsverfassungsgesetz und Nebengesetzen (3rd edn Beck, München 2007) § 935 para 2.

115 ibid para 14.
} 
disadvantage to the defendant, the plaintiff can be asked to bring almost full-trial evidence. ${ }^{116} \mathrm{~A}$ case is urgent if there is an objective danger that the change of the status quo will make it very difficult or impossible for the plaintiff to enforce his rights. ${ }^{117}$

Similarly to the grant of a permanent injunction, interim injunctions can be awarded against horizontal and vertical anticompetitive agreements and unilateral conduct. However, courts are said to be rather reluctant to awarded interim remedies aimed at the preliminary supply or access to infrastructure. The provisionally forced supply normally necessitates the existence of exceptional circumstances. ${ }^{118}$ Gathering information on German cases, ${ }^{119}$ it appears that claims on an interim basis are often rejected because the applicant fails to demonstrate the urgency of the application. However, there is no general obstacle to obtain an interim injunction such as the adequacy of damages. For example, in a case where the plaintiffs sought access to the defendant's airport to offer their shuttle service to passengers the court ordered the defendant to preliminary grant access to the airport in exchange for a fair payment. ${ }^{120}$ In a different proceeding the Higher Regional Court of Stuttgart confirmed that claims aimed at delivery or supply can be provisionally enforced by means of interim relief. ${ }^{121}$ In yet another case the Higher Regional Court of Düsseldorf had to decide on an interim basis whether or not the fixed amounts set by health funds for medical auxiliary material amounted to a violation of Articles 101 and $102 .{ }^{122}$ The interim relief sought by a taxi firm against the operator of a central taxi call was ultimately rejected on appeal. ${ }^{123}$ The applicant had asked the court to preliminarily order the defendant to broker taxi jobs for the applicant. Access to trade fairs and shows is often sought via interim relief. ${ }^{124}$ In those cases time is of particular importance as the plaintiff will usually lose the interest in a trade fair after it took place. In a very recent example a firm requested (unsuccessfully though) access to the after-game press conferences of the football team of Bayern Munich on both a permanent and preliminary basis. Although the

\footnotetext{
116 ibid para 15.

${ }^{117}$ Michael Huber in Hans-Joachim Musielak (ed), Kommentar zur Zivilprozessordnung: Mit Gerichtsverfassungsgesetz ( $7^{\text {th }}$ edn Vahlen, München 2009) $§ 935$ para 13.

118 Oberlandesgericht Frankfurt, 6 U Kart 36/90, Liefersperre für neuform-Waren [1990] NJW 166; Oberlandesgericht Düsseldorf, U (Kart) 9/02, Leistungsverweigerungsrecht des marktbeherrschenden Unternehmens bei Zahlungsverzug des Kunden [2002] MMR 108; Oberlandesgericht Düsseldorf, VI-U (Kart) 35/03, SIM-Karten in GSM-Gateways - call media services Ltd [2004] MMR 618.

${ }^{119}$ Peyer (n 59).

${ }^{120}$ Oberlandesgericht Koblenz, U 1274/09 Kart, Shuttledienst [2009] GRUR-RR 105.

${ }^{121}$ Oberlandesgericht Stuttgart, 2 U Kart 301/89, Diskriminierung durch Nichtgewährung von Sendezeit in der Hörfunkwerbung [1990] NJW-RR 940.

122 Oberlandesgericht Düsseldorf, U (Kart) 19/98, Inkontinenzhilfen [1998] EuZW 188.

${ }^{123}$ Oberlandesgericht Frankfurt, 6 U 51-84, Taxi-Funkzentrale [1984] GRUR 323.

${ }^{124}$ See just Oberlandesgericht Düsseldorf, VI-U (Kart) 8/08, Dentalmesse [2008] GRUR 272.
} 
claims were ultimately struck down there was and is no argument about the availability of permanent and preliminary injunctions. ${ }^{125}$

\section{Preliminary conclusion}

Plaintiffs can seek injunctions for the violation of Articles 101 and 102 and the German statutory provision governing anticompetitive agreements and unilateral conduct. There have not been cases in which the merger regulations were privately enforced and it is doubtful whether private parties can actually seek an injunction in order to prevent a merger. Injunctive relief as a means to enforce other provisions of the antitrust laws is widespread and has been applied in many industries. The majority of plaintiffs' applications for injunctive relief are based on allegations of anticompetitive unilateral behaviour or vertical restraints. Parties often assert refusals to deal or the denial of access to networks by a dominant or at least economically strong defendant. There were also cases in which the claimants felt excluded from a selective distribution system that fell into the realm of anticompetitive agreements under Article 101 or German law. Injunctive relief is also available against cartels. ${ }^{126}$ The survey of the case law did not reveal an instance where a structural remedy was awarded.

Most of the cases mentioned above include elements of contract disputes or are underpinned by failed negotiations which, subsequently, lead to a trial. Particularly actions that are based on the abuse of dominance or anticompetitive vertical restraints have many elements of contract litigation. Whether or not antitrust plaintiffs gain an advantage when they refer to the competition law statutes in contract disputes cannot be said without a further analysis of the case law. As there are no special rules for antitrust injunctions in German law so far, the plaintiff's advantages, if any, may not be significant. Closely connected with the practice of solving contract disputes by antitrust means is the question of whether judges too readily accept antitrust remedies in those proceedings.

Overall, the factors that cause the relatively large number of injunctive relief requests have not been fully identified yet. It may be an idiosyncrasy of German law - section 20 ARC does not require dominance but relative economic strength for some types of anticompetitive conduct. But it may also a form-based rather than an effects-based approach that eases the evidentiary burden on the

\footnotetext{
125 Oberlandesgericht München, U (K) 3946/09, FC Bayern im Web-TV [2010] GRUR-RR 258.

${ }^{126}$ Stromeinspeisung (n 95); Emmerich (n 61) para 102.
} 
parties and, thus, reduces the cost of legal action. ${ }^{127}$ If it holds true that cases are assessed on a more legalistic basis, it may lead to higher error costs as one would assume that the number of errors made by judges increases. The form and effects-based approach for the assessment of anticompetitive conduct has sparked considerable debate in Germany and Europe. ${ }^{128}$ Low legal cost could contribute to the magnitude of private injunction actions, notwithstanding the fact that they may stem from the form-based approach itself. Finally, one of the factors I have hinted at in this paper is the plaintiff-friendly arrangement with regards to injunction and removal claims. The availability of injunctive relief is neither in question nor is there a ranking between different remedies. Injunctive relief is on a par with damages actions. If the conditions for both claims are met, the plaintiff can choose the most suitable remedy or both. Injunctions may be more useful to finally solve the conflict with effect to the future while damages appear to be the first choice remedy when there is no current or future problem to be removed but a past harm to be remedied. A potential plaintiff may easily master the legal requirements to obtain an injunction, especially as no harm and causation between the harm and the violation is to be shown.

\section{E. Antitrust injunctions in England and Wales}

In this section I will look at the principles governing injunctive relief in England and Wales. Dealing with the legal requirements for the grant of injunctive relief, I will show possible explanations for the differing magnitude of antitrust injunctions in Germany and England. ${ }^{129}$ The first part is devoted to antitrust injunctions in general. In the second part I will look at interim injunctions. ${ }^{130}$

\footnotetext{
${ }^{127}$ The abovementioned issue of contract cases as well as the form and effects-based assessment of anticompetitive conduct in private litigation are subject to research currently undertaken.

${ }^{128}$ Wernhard Möschel, 'Juristisches versus ökonomisches Verständnis eines Rechts der Wettbewerbsbeschränkungen' in Erhard Keller, Clemens Plassmann and Andreas von Falck (eds), Festschrift für Winfried Tilmann: Zum 65. Geburtstag (Heymann, Köln 2003); Ulrich Immenga, 'Ökonomie und Recht in der europäischen Wettbewerbspolitik' (2006) 4 Zeitschrift für Wettbewerbsrecht 346-366; Dieter Schmidtchen, Max Albert and Stefan Voigt (eds), The More Economic Approach to European Competition Law (Mohr Siebeck, Tübingen 2007). For the potential effects on private antitrust enforcement see, for instance, Ulf Böge and Konrad Ost, 'Up and Running, or Is It? Private Enforcement - The Situation in Germany and Policy Perspectives' (2006) 27 European Competition Law Review 197-205; Jürgen Basedow, 'Das Kartelldeliktsrecht und der "More Economic Approach"' (2006) Europäische Zeitschrift für Wirtschaftsrecht 97; Wulf-Henning Roth, 'Private Enforcement of European Competition Law - Recommendations Flowing from the German Experience' in Jürgen Basedow (ed), Private Enforcement of EC Competition Law (Kluwer Law International, Alphen a. d. Rijn 2007) 61.

${ }^{129}$ See Rodger (n 6); Rodger (n 6); Barry J Rodger, 'UK Competition Law and Private Litigation' in Barry J Rodger (ed), Ten Years of UK Competition Law Reform (Dundee University Press, Dundee 2010) 53; Peyer (n 59).

${ }^{130}$ For a general overview about injunction see Gee (n 21); Bean (n 21).
} 


\section{Permanent injunctions}

Injunctions are an equitable remedy and could only be granted by the High Court of Justice. ${ }^{131}$ With the enactment of the Supreme Court Act 1981 and the County Courts Act 1984 all divisions of the High Court and the County Courts were given the discretionary powers required to rule on requests for injunctions. The High Court of Justice, which has the exclusive jurisdiction for antitrust cases based on alleged violations of EU or UK competition law, ${ }^{132}$ enjoys the powers to rule on injunction requests. According to section 37 of the Supreme Court Act, the Court can grant injunctions when it is "just and convenient to do so." Injunction orders "may be made either unconditionally or on such terms and conditions as the court thinks just." Furthermore, the Civil Jurisdiction and Judgement Act 1982 mentioned the High Court's powers to grant interim relief in section 25. The Civil Procedure Rules also refer to interim relief in rule 25.1. The Competition Appeal Tribunal, to which victims can refer with a follow-on claim, only has the powers to rule on monetary follow-on actions for the violation of the antitrust rules according to sections 47A and 47B of the Competition Act 1998. Whether or not plaintiffs can obtain an interim injunction in proceedings before the Competition Appeal Tribunal will be briefly discussed in part II below. ${ }^{133}$

The principles governing permanent or perpetual injunctions in English antitrust law stem mostly from non-antitrust cases. Injunctions are sought to prevent a tort from continuing or to occur in the first place ${ }^{134}$ Injunctions can be mandatory or prohibitory in form. Mandatory injunctions require some positive act to be done by the person enjoined, for example, to pull down a building or to provide information. Prohibitory injunctions restrain the commission of an act. The defendant complies with it through doing nothing. ${ }^{135}$ An injunction may be issued to restrain a threatened act that, unless restrained, is likely to be repeated, with the result that the claimant will then have an action based on a civil law wrong. ${ }^{136}$ A prohibitory injunction is normally ordered when the violation is recurrent. ${ }^{137}$ In general, courts tend to grant damages rather than injunctions. As for the different types of injunctions, courts will be more cautious towards an application for a mandatory injunction

\footnotetext{
${ }^{131}$ Bean (n 21) 1.04.

${ }^{132}$ See para 2.1 of the Practice Direction - Competition Law - Claims Relating to the Application of Articles 81 and 82 of the EC Treaty and Chapters I and II of Part I of the Competition Act 1998.

${ }^{133}$ See footnote 157.

${ }^{134}$ Deakin, Johnston and Markesinis (n 10) 1029.

${ }^{135}$ Gee (n 21) 2.002.

${ }^{136}$ Deakin, Johnston and Markesinis (n 10) 1030.

137 ibid 1031.
} 
compared with an application for a restrictive (prohibitory) injunction. ${ }^{138}$ In his non-exhaustive list of purposes for which injunctions can be granted, Bean noted that there are hardly any mandatory injunctions. ${ }^{139}$

In the English system an injunction is a remedy that stems from equity; that is a remedy entirely at the discretion of the judge. In contrast, damages are awarded as of right. If the plaintiff is entitled to damages as of right, he will obtain the remedy if he brings his case to court, follows the right procedure and submits the necessary evidence. The ordering of an injunction, on the other hand, is at the discretion of the judge; it means that even if the applicant shows that his right is being infringed, he may be refused the injunction and left to his remedy in damages. The court can also deny an application for injunctive relief because of the behaviour of the plaintiff or where the interference with the plaintiff's rights is marginal. ${ }^{140}$ However, the powers of the court to grant or refuse an injunction are not unfettered as there is a body of case law laying out the conditions for granting or refusing applications for injunctions. ${ }^{141}$ There is one overriding requirement regardless of the circumstance of the case in question. The victim applying for injunctive relief must have a cause of action in law entitling him to substantive relief. ${ }^{142}$ An injunction is not a cause of action like a tort or a breach of contract but a remedy. Consequently, the plaintiff needs a recognised right, such as an individual right stemming from Articles 101 and 102 or English competition law, which provides the basis for the relief sought.

In order to obtain a permanent or perpetual prohibitory or mandatory injunction the plaintiff must satisfy the court that damages are not an adequate remedy. An injunction cannot be awarded for actionable wrongs for which damages are the proper remedy. ${ }^{143}$ If the claimant can be fully compensated by damages, no injunction will be awarded. Consequently, an injunction requires an ongoing or recurrent infringement of law. If the injury is small, it can be estimated and compensated in money and it would be oppressive to the defendant to grant an injunction, the case calls for damages as a substitution for an injunction. ${ }^{144}$ As the grant of an injunction is at the discretion of the

\footnotetext{
${ }^{138}$ Court of Appeal, Durell v Pritchard (1865) 1 Ch.App. 244, 250; House of Lords, Morris v. Redland Bricks [1969] A.C. 652, 665. Mandatory injunctions are less common than the prohibitory type, and are likely, other things being equal, to be more drastic in their effect. A mandatory injunction is seldom granted as an interim measure. Courts prefer to hear full evidence on both sides before attempting to compel positive action. Bean (n 21) 1.02.

${ }^{139}$ Court of Appeal, Armstrong v. Sheppard and Short Ltd. (1959) 2 Q.B. 384; Bean (n 21) 1.20.

${ }^{140}$ Bean (n 21) 2.02.

141 ibid 1.10.

142 ibid 1.04.

${ }^{143}$ Lindley L.J. in Court of Appeal, London and Blackwall Railway Company v Cross (1886) 31 Ch. D. $354,369$.

${ }^{144}$ Court of Appeal, Shelfer v City of London Electric Lighting Co (1894) 1 Ch. 287.
} 
judge, there are several factors that should be taken into account and which could tip the balance in favour of the applicant or defendant. For example, delaying the application for injunctive relief or dishonest or improper conduct may become an equitable bar to the plaintiff's application.

A special form of injunctions is the quia timet injunction against threatening infringements. In Redland Bricks Ltd v. Morris the judges were faced with a mandatory quia timet injunction sought against a defendant. ${ }^{145}$ The applicant in the lower court feared that harm that had already been done by the defendant before the trial could lead to further damage in the future. To prevent more potential damage the initial claimant sought an order obliging the defendant to undertake necessary pre-emptive measures. This is a situation in which the quia timet action applies; situations where the plaintiff is not harmed yet (but the loss is threatening) or when the plaintiff has been compensated but the past action of the defendant might lead to further causes of action in the future. ${ }^{146}$ According to Lord Upjohn, mandatory injunctive relief is available to plaintiffs if they can show that there is a very strong probability that they will suffer grave damage in the future. ${ }^{147}$ There seems to be an emphasis on both a high probability that harm will occur and the seriousness of the damage. Second, a damages remedy must be inadequate given the nature of the injury. This requirement is the application of the general principle of equity. ${ }^{148}$ Finally, the court must also take into account the costs that are likely to occur on part of the defendant if the mandatory injunction is granted and the defendant has to undertake certain works. ${ }^{149}$ This is thought to exclude injunction requests in cases in which such a remedy would be a hardship to the defendant, for example, were invasions of the plaintiff's rights happened by accident rather than by intent. ${ }^{150}$ Consequently, the defendant's costs weigh less if there was a wilful violation of the law. The costs to the defendant are of less importance in cases where the plaintiff seeks a negative injunction against the continuance or recurrence of a wrongful act. ${ }^{151}$ If the court is convinced that a mandatory injunction should be granted, it still needs to properly phrase the injunctive court order so as to allow the defendant to

\footnotetext{
${ }^{145}$ Morris v. Redland Bricks (n 139).

146 ibid 665. "A quia timet ("since he fears") injunction is an injunction granted for the purpose of preventing what would be an actionable wrong if it was committed. Either the defendant has threatened a wrongful act or there is a real risk that unless an injunction is granted an actionable wrong will be committed." Gee (n 21)

2.003 .

${ }^{147}$ Morris v. Redland Bricks (n 139) 665.

148 ibid.

149 ibid 666.

${ }^{150}$ Court of Appeal, Daniel v Ferguson [1891] Ch. 27; High Court of Justice, Kelsen v Imperial Tobacco Co (1957) 2 Q.B. 334, 347.

${ }^{151}$ Morris v. Redland Bricks (n 139) 666.
} 
know exactly what to do. ${ }^{152}$ The court order must be clear and explicit. Especially in more complicated circumstances the defendant should know what he has to do.

There have been just a few cases in which a permanent or perpetual antitrust injunction was considered by the courts. In Attherace $v$ British Horseracing Board the claimants' request for an injunction was rejected upon appeal. ${ }^{153}$ The claimants asserted that the defendant abused a dominant position while supplying horse racing data to the plaintiffs. The Court of Appeal did not agree and cleared the defendant of the alleged abuse of a dominant position because it did not find that there was excessive pricing or discrimination. If any abuse occurred, it would have been by way of overcharging for which no evidence had been presented before the High Court of Justice. Etherton J., who had ruled in favour of the claimants in the first instance, left the question of the appropriate form of relief open to further arguments. In assessing the case, the Court of Appeal took an interesting stance:

\begin{abstract}
"The nature of these difficult questions suggests that the problems of gaining access to essential facilities and of legal curbs on excessive and discriminatory pricing might, when negotiations between the parties fail, be solved more satisfactorily by arbitration or by a specialist body equipped with appropriate expertise and flexible powers. The adversarial procedures of an ordinary private law action, the limited scope of expertise in the ordinary courts and the restricted scope of legal remedies available are not best suited to helping the parties out of a deadlocked negotiating position or to achieving a business-like result reflecting both their respective interests and the public interest. These are not, however, matters for decision by the court, which must do the best that it can with a complex piece of private law litigation." 154
\end{abstract}

The fact that the private antitrust proceeding was based on failed negotiations of a contract is remarkable in so far, as Etherton J. generally disapproved of the general court being the right forum to (re)negotiate the contract (and antitrust) issues. It is also noteworthy, particularly in the light of the discretion judges enjoy when granting injunctive relief, that he felt the court's authority being limited and called for more flexible powers.

The claimants in Bookmakers' Afternoon Greyhound Services Ltd v Amalgamated Racing Ltd unsuccessfully sought an injunction for the violation of Article 101 and section 2 of the Competition Act $1998 .{ }^{155}$ In addition to damages and other supporting relief, the claimants asked the court to

\footnotetext{
152 ibid.

${ }^{153}$ High Court of Justice, Attheraces Ltd \& Anr v The British Horseracing Board \& Anr [2005] EWHC 3015; Court of Appeal, Attheraces v British Horseracing Board [2007] EWCA Civ 38.

${ }^{154}$ Attheraces $v$ British Horseracing Board (n 154) para 7.

${ }^{155}$ High Court of Justice, Bookmakers' Afternoon Greyhound Services Ltd v Amalgamated Racing Ltd [2008]

EWHC 1978; Court of Appeal, Bookmakers Afternoon Greyhound Services Ltd v Amalgamated Racing Ltd [2009] U.K.C.L.R. 863.
} 
order an injunction preventing the defendants from implementing the collective exclusive licensing practice. ${ }^{156}$ The High Court of Justice and the Court of Appeal held that the licensing practice between racecourses did not have the object of fixing prices or the effect of foreclosure. Consequently, there was no cause of action on which an injunction could have been based and both the first instance claim and the appeal were dismissed.

As far as permanent injunctions are concerned there have not been many cases, particularly no successful proceedings, in which the plaintiff sought a prohibitory or mandatory injunction. Although injunctions can be used to stop current violations of the law and to prevent further harm where future damages are difficult to work out, they have not been utilised often in antitrust proceedings before the English courts.

\section{Interim relief}

Interim injunctions are ordered by the court ${ }^{157}$ directed at a party to carry out or refrain from doing an act without providing a final dispute resolution. ${ }^{158}$ The objective of an interim injunction is to safeguard the status quo. ${ }^{159}$ In general, a prohibitory interim injunction is likely to be granted according to the guidelines outlined by Lord Diplock in American Cyanamid Co. v Ethicon Ltd. ${ }^{160}$

\footnotetext{
${ }^{156}$ Bookmakers' Afternoon Greyhound Services Ltd v Amalgamated Racing Ltd ( $\mathrm{n} 156$ ) para 80.

${ }^{157}$ There is also the question whether or not the Competition Appeal Tribunal (CAT) may impose interim measures. It can order the defendant to make an interim payment of a reasonable amount of the damages that he is likely to pay after the CAT has made its judgement. According to CAT Rule 61(1)c the Tribunal may grant any remedy on an interim basis for which it would have the power to make a final decision. Whether this applies to interim relief for third parties under section 47A of the Competition Act is arguable. Usually, appeals against an OFT decision are made before the CAT. Only under section 47A the CAT can award damages or any sum of money to third parties following an infringement decision of the OFT or European Commission. In respect to third parties' damages claims, the CAT only carries the power to decide on monetary awards but not on findings of facts and law. This implies a limitation on interim measures the CAT can grant. As the breach of a competition law provision is no longer in dispute, this may suggest that the Tribunal solely possesses the power to grant interim remedies related to the damages award but not to the infringement itself. It can be argued that the CAT, although not having the authority to challenge an OFT or Commission decision in private antitrust proceedings, is authorised to end an anti-competitive behaviour if the illegal conduct has been established prior to the CAT trial. On the other hand, the clear wording of section 61(1)c CAT Rule argues against those powers. To grant other interim injunctions concerning the infringement in follow-on claims the Tribunal would need the authority to decide upon an infringement. In fact, the CAT only adjudicates on damages.

${ }^{158}$ Adrian A S Zuckerman, Zuckerman on Civil Procedure: Principles of Practice $\left(2^{\text {nd }}\right.$ edn Thomson/Sweet \& Maxwell, London 2006) 296. For the interim relief in English competition law before the Competition Act 1998 see Christopher Bright, 'Interim Relief in UK Competition Law' (1992) 13 European Competition Law Review 21-33.

${ }^{159}$ Andrew Keay, 'Whither American Cyanamid?: Interim Injunctions in the 21st Century' (2004) 23 Civil Justice Quarterly 132-151, 132.

${ }^{160}$ House of Lords, American Cyanamid Co. v Ethicon Ltd. [1975] A.C. 396.
} 
Those principles are not fully applied to mandatory interim injunctions as mandatory injunctions are much stronger in their effect and, thus, require an unusually strong and clear case. ${ }^{161}$ As for prohibitory interim relief under the American Cyanamid rule, the claimant has to show that a serious question is to be tried, damages are not an adequate remedy for the party and the balance of convenience lies with the claimant.

To satisfy the first prerequisite the plaintiff does not need to show a prima facie case; that is that the he is more likely than not to obtain a final injunction based on the evidence. This approach was considered and rejected by the House of Lords in American Cyanamid Co. v Ethicon Ltd. ${ }^{162}$ The evidence that is made available to the judge is necessarily incomplete - one of the reasons why judges are given wide discretion to decide on an application for interim relief. Instating a formal rule, like a prima facie case or a 50 per cent rule as to the probability of success, would significantly reduce the discretion. At this stage of the litigation process the court does not try to resolve the conflict before him. The task is to filter out claims that are vexatious or frivolous. ${ }^{163}$ As the court does not fully evaluate the evidence, it is sufficient if the court is satisfied that a serious question is brought before it. While this could be understood as barring the court from assessing the relative strengths of the parties' cases, Laddie J. in Series 5 Software Ltd v Clarke held that the judge can have an early and non-binding view on the strength of the case before him and, thus, reject an application for interim relief based on an arguable but weak case. ${ }^{164}$ It is said that Laddie J. reaffirmed the flexibility of injunctive relief. ${ }^{165}$

If the court is satisfied that a serious issue is to be tried, it must then go on and consider whether or not damages are an adequate remedy. If damages would adequately compensate the claimant for the temporary loss sustained, he can provide a satisfactory undertaking as to the damage, and such an undertaking would adequately compensate the defendant if he is to win, an interim injunction may be granted. ${ }^{166}$ The adequacy of damages tipped the balance in favour of the defendants in Garden Cottage Foods Ltd v Milk Marketing Board - an important competition law decision in the UK. ${ }^{167}$ The House of Lords held that damages are an adequate remedy and available in cases in which the defendant violated competition rules. Confirming that a monetary claim for antitrust breaches

\footnotetext{
${ }^{161}$ Court of Appeal, Leisure Data v Bell [1987] F.S.R. 367.

${ }^{162}$ American Cyanamid Co. v Ethicon Ltd. (n 161).

163 ibid 408.

${ }^{164}$ High Court of Justice, Series 5 Software Ltd v Clarke \& Others [1995] C.L.C. 631.

165 Jonathan Steinert and Alexander Pelling, 'Interlocutory Relief: Interpreting American Cyanamid' (1997) 8 International Company and Commercial Law Review 178-180. For further discussion see Bean (n 21) 3.17.

${ }^{166}$ American Cyanamid Co. v Ethicon Ltd. (n 161) 408.

${ }^{167}$ House of Lords, Garden Cottage Foods Ltd v Milk Marketing Board [1983] A.C. 130 (HL).
} 
can be made, the court set the bar high for interim relief and rejected the application for an interlocutory injunction. ${ }^{168}$ Interim relief will only be granted if there is a doubt as to the adequacy of damages; i.e. if the loss is irreparable or damages are unjust. ${ }^{169}$

The third condition laid out in American Cyanamid is the balance of convenience.

"It is where there is doubt as to the adequacy of the respective remedies in damages available to either party or to both, that the question of balance of convenience arises. It would be unwise to attempt even to list all the various matters which may need to be taken into consideration in deciding where the balance lies, let alone to suggest the relative weight to be attached to them. These will vary from case to case." ${ }^{170}$

The balance of convenience is a weighing of the hardship that will inevitably fall on one party or the other if the court has reached this stage of the decision making process. The balance of convenience is probably best described as the judge's power to exercise discretion taking into account all other factors apart from those considered at the 'serious issue to be tried' and 'adequacy of damages' steps. ${ }^{171}$ It is difficult to enumerate all possible consideration that could tilt the balance in favour of one of the parties. Consequently, it is next to impossible to give a more exact definition of the balance of convenience as it was already given by Lord Diplock in American Cyanamid. For example, if the injunction would alter the status quo, courts are less likely to concede interim relief; a weighing that takes place at the balance of convenience step. Under the balance of convenience judges may create exceptions to American Cyanamid and have done so. According to Lord Diplock in $N W L L t d v$ Woods, one of the special cases that requires slightly different considerations is a situation in which the grant or refusal of interim relief will practically bring an end to the dispute. ${ }^{172}$ In those cases courts must take into account the potential effect of the injunction in order to avoid injustice as it would practically deny the defendant or the applicant the right to trial. ${ }^{173}$

The approach suggested by Lord Diplock in American Cyanamid has received a mixed reception. ${ }^{174}$ Although most courts seem to follow American Cyanamid there have been notable exceptions like,

\footnotetext{
${ }^{168}$ For critical comments on this approach see, for instance, the dissenting opinion of Lord Wilberforece or Rodger and MacCulloch ( $\mathrm{n}$ ).

${ }^{169}$ Mark Brealey and Mark Hoskins, Remedies in EC Law: Law and Practice in the English and EC Courts ( $2^{\text {nd }}$ edn Sweet \& Maxwell, London 1998) 151; Tim Ward and Kassie Smith, Competition Litigation in the UK (Sweet \& Maxwell, London 2005) 169.

${ }^{170}$ American Cyanamid Co. v Ethicon Ltd. (n 161) 408.

${ }^{171}$ Gee (n 21) 2.003.

172 House of Lords, NWL Ltd $v$ Woods (The Nawala) (No.2) [1979] W.L.R. 1294.

173 ibid 1306.

174 John Leubsdorf, 'The Standard for Preliminary Injunctions' (1978) 91 Harvard Law Review 525; Adrian A S Zuckerman, 'Interlocutory Injunctions on the Merits' (1991) 107 Law Quarterly Review 196-201; Keay (n 160).
} 
for instance, Laddie J.'s ruling in Series 5 Software Ltd $v$ Clarke. ${ }^{175}$ Keay observed that some judges applied American Cyanamid but it has also been frequently side-stepped. ${ }^{176}$ Especially when courts created exceptions, they refrained from referring to this case or asserted that the facts justified an exception to American Cyanamid. Furthermore, the changes in case management triggered by the Civil Procedure Rules made the American Cyanamid principles less critical. ${ }^{177}$

Since the assessment of the case in preliminary trials is of preliminary nature, it may happen that the applicant received an interim injunction but failed to obtain a final court order. The unjustly restrained defendant will be normally entitled to damages for the loss suffered from the interim constraint. Thus, the courts have established a practice requesting the plaintiff to undertake to pay any damages as compensation if the court rejects the application for a permanent injunction. ${ }^{178}$

The first interim competition law case that was decided on the basis of the American Cyanamid standard was Chelmkarm Motors Ltd v Esso Petroleum and others. ${ }^{179}$ The applicant sought an interim remedy against Esso and other petrol suppliers which allegedly subsidised their tied retailers in times of price cuts. The plaintiff was an independent petrol retailer who argued that without these practices, which violated Articles 101 and 102 (Articles 85 and 86 at that time), his business would have been profitable. Goulding J. accepted that there was a serious issue to be tried but held that damages were an adequate remedy. The difficulties of calculating damages for foregone profits were not held to be insurmountable. The court also recognised that the plaintiff was financially weaker than the defendants not being able to afford the cross-undertakings in damages.

An early interim injunction case in the UK based on infringements of the competition law was the abovementioned Garden Cottage Foods Ltd v Milk Marketing Board ${ }^{180}$ - the most significant UK case so far. ${ }^{181}$ The defendant refused to deliver bulk butter to the claimant. Parker J. rejected the plaintiff's injunction request as damages were the appropriate remedy in this case. Lord Denning, however, hearing the appeal thought that an injunction would be the only effective remedy

\footnotetext{
${ }^{175}$ Series 5 Software Ltd v Clarke \& Others (n 165).

${ }^{176}$ Keay (n 160) 143.

177 ibid.

178 Bean (n 21) 3.03.

${ }^{179}$ High Court of Justice, Chelmkarm Motors Limited v Esso Petroleum Company Ltd and others [1978] CMLR 73.

${ }^{180}$ Court of Appeal, Garden Cottage Foods Ltd v Milk Marketing Board [1982] Q.B. 1114; Garden Cottage Foods Ltd $v$ Milk Marketing Board (n 168). There is an even earlier request for injunctive relief which was not reported. High Court of Justice, James Budgett \& Son Ltd v. British Sugar Corporation Ltd (1979) 4 European Law Review 417. Parker J. granted ex parte interim relief restraining the defendant from refusing to accept orders for sugar. The case was subsequently settled.

${ }^{181}$ Rodger and MacCulloch (n 4) 395.
} 
available in such a case. ${ }^{182}$ Overturning the decision of the Court of Appeal, the House of Lords held that damages were an appropriate remedy. At the same time, it was clarified that a right to damages for the violation of EU competition law rules exist. ${ }^{183}$ Dissenting, Lord Wilberforce pointed out that the EU prohibition of abuse of dominance has direct effect which, in turn, requires an action to prohibit the abuse under national law. Thus, an action lies for an injunction to restrain the prohibited conduct. Furthermore, as damages are rather uncertain, it would be better to allow an injunction rather than referring the plaintiff to hypothetical damages. ${ }^{184}$

Following the House of Lords in Garden Cottage Foods, the Court of Appeal rejected an application for an interlocutory injunction in Leyland DAF Ltd v Automotive Products plc. ${ }^{185}$ Leyland DAF had been forced in to receivership and Automotive Products, one of Leyland's suppliers, refused to delivery more parts until the existing debts of Leyland with Automotive were settled. Subsequently, Leyland DAF sought the continuation of delivery through an interim injunction based on the violation of Article 102 (Article 86 at that time). Although the parts delivered by the defendant were crucial to the production of Leyland, the courts decided that withholding supplies until debts for previous deliveries have been paid was a normal feature of a commercial dispute and, thus, did not amount to an abuse of dominance on part of Automotive Products plc. There was no seriously arguable case. $^{186}$

A year after the House of Lords handed down the decision in Garden Cottage Foods Ltd, Lawson J. granted interim relief applying the American Cyanamid test in Cutsforth v Mansfield Inns Ltd ${ }^{187}$ The defendant had bought a number of pubs and introduced a new policy for the tenants of the premises whereby all tenants had to operate amusement equipment from the defendant's list of nominated suppliers. The defendants refused to place the plaintiff on the list. The plaintiff asserted that the defendant's refusal would violate, inter alia, Articles 101 and 102 (Articles 85 and 86 of the Treaty of Rome) and sought interim relief. The court granted the interim injunction barring the defendant from requiring the tenants to terminate their agreements with the plaintiff as this was contrary to Block Exemption Regulation 1984/83 and, thus, not in line with Article 101. Whether or not European law is violated is a serious question to be tried and damages would not adequately compensate the plaintiff as it had required the plaintiff to basically end its business. As for the

\footnotetext{
${ }^{182}$ Garden Cottage Foods Ltd v Milk Marketing Board (n 181) 1125.

${ }^{183}$ Garden Cottage Foods Ltd v Milk Marketing Board (n 168).

184 ibid 151.

${ }^{185}$ Court of Appeal, Leyland DAF Ltd v Automotive Products plc [1993] BCC 389.

186 ibid 395.

${ }^{187}$ High Court of Justice, Cutsforth v Mansfield Inns Ltd [1985] CMLR 1.
} 
serious issue to be tried, the court posed the question whether or not the imposed policy is an ancillary restraint to tied house agreements under Article 101. While considering the relevant EU law, the judge, although not explicitly, seemed to indicate that the plaintiff's case may have some success as the restriction imposed by the defendant on the tenants is not exempted under the Block Exemption Regulation 1984/83. Damages were not found to be an adequate remedy because "[...] the denial of interim relief would virtually put an end to a business which has operated with a degree of success over a period of 15 years or more." 188

An interim injunction for the potential breach of antitrust law was also granted in Holleran v. Daniel Thwaits. ${ }^{189}$ The defendant owned tied public houses and intended to amend the standard tenancy agreement. The plaintiffs refused to sign the new agreements for their pubs as they deemed them contrary to Article 101 (formerly Article 85). The court held that it has the power to restrain a landlord from abusing its contractual right to terminate a tenancy. The plaintiffs showed that the only purpose of the amendment was to procure a breach of European law by requiring the tenants to enter into an agreement illegal under EU antitrust rules and obtained a prohibitory injunction. ${ }^{190}$ Applying the American Cyanamid guidelines, Gibson J. was satisfied that the plaintiffs had shown an arguable case. ${ }^{191}$ The defendant argued that its business would fall under the de minimis rule. The court rejected this argument by saying that it is "[...] strongly arguable that the agreement does not satisfy the provisions of the Regulation [1984/83] and accordingly that there are various provisions of the agreement which will be void under Article 85(1) and (2)." ${ }^{192}$ This is not quite the language used in American Cyanamid. Gibson J. appears to denote the strength of the case as opposed to test the seriousness of the issue to be tried, similarly to Lawson J. in Cutsforth v Mansfield Inns Ltd. According to Lord Diplock, the serious issue to be tried is supposed to remove vexatious or frivolous claims. ${ }^{193}$ As to the adequacy of damages, the court found that the livelihood of the plaintiffs was in danger if the interim remedy was not granted. The defendants accepted the cross-undertaking in damages offered by the plaintiffs. Notwithstanding the fact the Gibson J. was already convinced that an injunction should clearly be granted under American Cyanamid, he briefly discussed the balance of convenience rejecting the defendant's arguments as to the hardship of an injunction.

\footnotetext{
188 ibid para 37.

${ }^{189}$ High Court of Justice, Holleran v Daniel Thwaites PIc [1988] CMLR 917.

190 ibid para 52.

191 ibid.

192 ibid para 40. (emphasis added).

${ }^{193}$ American Cyanamid Co. v Ethicon Ltd. (n 161) 408.
} 
In another early competition law case the defendant's defence against a claim for interim relief prompted Rimer J. to expressively state that interim relief can be sought against a violation of Article 102. The plaintiff in Sockel GmbH v The Body Shop International Plc was the Austrian head franchisee of the defendant. ${ }^{194}$ Being unsatisfied with the service of the plaintiff, Body Shop started supplying the sub-franchisees directly, whereas before goods were supplied to the head franchisee to be further delivered to the sub-franchisees. Applying the American Cyanamid standard, Rimer J. refused the argument that the mere existence of a franchise structure put the defendant in a dominant position. However, he went beyond the American Cyanamid test stating that the claim did not have a realistic prospect of success in trial. Further assertions that the defendant was dominant in other markets for cosmetic products were rejected for the lack of evidence. Since the evidence did not suffice to satisfy the court that the defendant enjoyed a dominant position, Rimer J. held that no serious issue was to be tried. Interestingly, the court claimed that it followed American Cyanamid but, at the same time, tested the prospect of success of the claim. Furthermore, the injunctive relief that had to be granted if successful would have been mandatory rather than prohibitory by nature posing the question whether or not American Cyanamid would have been the appropriate standard.

A successful application for interim relief was made in Software Cellular Network v T-Mobile (UK) $L t d .{ }^{195}$ This case involved an interim application from Software Cellular Network requiring T-Mobile to activate the plaintiff's telephone numbers as all other mobile network operators in the UK had done. The plaintiff provided VoiP services enabling its customers to call and receive calls over the Internet while using a standard telephone number. To receive calls on the standard telephone number other mobile phone operators had to activate the applicant's numbers. T-Mobile refused to activate the numbers as the parties could not agree on the rates for T-Mobile's services. Software Cellular Network claimed that the refusal to activate is an abuse of dominance without objective justification. Robin Knowles CBE, Q.C. granted the injunction as the application satisfied the American Cyanamid test. The judge assessed the statements of the parties especially with regards to the dominant position of T-Mobile. Deciding in favour of the plaintiff, the court held that an abuse of dominance was seriously arguable although the judge appeared to be more cautious in giving directions as for the prospect of success in trial. The adequacy of damages was denied on the grounds that the applicant's commercial survival was in question if it had to await trial. It would be impossible to quantify the loss the plaintiff suffers as a result of its inability to provide its services. ${ }^{196}$ As all other mobile network operators had activated the claimant's numbers and the interim charges

\footnotetext{
${ }^{194}$ High Court of Justice, Sockel GmbH v The Body Shop International PIc [1999] U.K.C.L.R. 262.

${ }^{195}$ High Court of Justice, Software Cellular Network v T-Mobile (UK) Ltd [2007] U.K.C.L.R. 1663.

${ }^{196}$ ibid para 32.
} 
for services were suggested by T-Mobile, the court found that without the interim remedy there would be either no service at all or only a materially compromised service on part of the plaintiff. Consequently, the balance of convenience was with the applicant. ${ }^{197}$ Although applying the American Cyanamid test, the judge dealt with an application for mandatory interim relief ordering the defendant to activate the plaintiff's telephone numbers. Thus, the judge discussed whether a high degree of assurance is required to make a mandatory order against the defendant. The court was not convinced that the case would match this standard. However, it was satisfied that the risk of injustice if the interim order was refused outweighed the risk of injustice if it was granted. ${ }^{198}$ Ordering T-Mobile to activate the numbers, the only injustice was that T-Mobile was being forced to do what all other mobile network operators were doing. ${ }^{199}$

In Claritas (UK) Ltd v Post Office the applicant sought an interim injunction restraining the Post Office from allowing the use of its "Royal Mail" brand name in a postal survey. ${ }^{200}$ Post Office and Postal Preference Service Ltd, the latter is partly owned by the Post Office and a competitor of Claritas, had agreed to use the Royal Mail logo and brand on a survey of consumers. Post Office allegedly infringed chapter II of the Competition Act 1998 and Article 102 (formerly 86) by granting an exclusive licence to Postal Preference Service Ltd. Collins J. did not order interim relief in favour of the applicants because no serious issue was to be tried. ${ }^{201}$ The applicant did not make it plausible that a dominant position in the market for letters by Royal Mail was likely to be extended into the secondary market for surveys (leveraging). According to Collins J., "[...] there is no possible basis in the evidence for classifying the licensing of the Royal Mail brand or logo in connection with its collection and exploitation of direct mail data as an abuse. Even if it were an abuse there is no basis for treating that market as a relevant market for the purposes of section 18 [Competition Act 1998]." 202

An interim injunction was obtained by Attherace in its law suit against the British Horseracing Board, Attherace $v$ British Horseracing Board. ${ }^{203}$ The High Court refused to strike out the perpetual injunction claim and, at the same time, awarded an interim prohibitory injunction to the applicants until further judgement. According to the court order, the defendants had to restrain from ordering, instructing, requesting or otherwise soliciting or encouraging their contractual partners or anyone

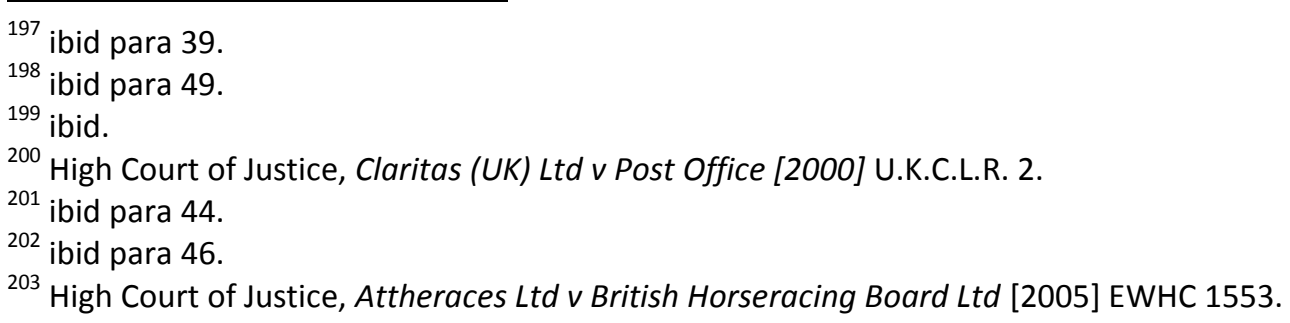


else to cut off or otherwise interfere with the supply of pre-race data to Attherace. ${ }^{204}$ Relying on the reasons for which the strike out application was rejected, the court also held that a serious issue is tried. In doing so, the court indirectly referred to the questions, whether the claim had a "real prospect of success." ${ }^{205}$ Although the real prospect of success was first considered in the light of the strike-out application, the court stressed that the reasons that argued in favour of dismissing the application to strike out the case also made it a serious issue to be tried. The balance of convenience was with Attherace provided they continue adequate payments pending judgement. If the supply of race data were to be stopped, it would be difficult to properly compensate the business in money. The balance of convenience and the status quo favoured the grant of an injunction. ${ }^{206}$ Damages payments were not deemed to be adequate since the loss to the business could not be properly compensated in monetary terms. ${ }^{207}$

Laddie J., who held that the judge can have an early view on the strength of the plaintiff's case in Series 5 Software Ltd $v$ Clarke, ${ }^{208}$ rejected applications for interim injunctions for precisely this reason - arguably weak cases - in Getmapping PIc v Ordnance Survey and Suretrack Rail Services Ltd $v$ Infraco JNP $L t{ }^{209}$ Both proceedings involved an application for a mandatory injunction (the latter could have been prohibitory, too). In both decisions Laddie J. stated:

"Put in simple terms, applications for interlocutory relief, whether mandatory or prohibitory, should not be seen as means by which a court can be persuaded to grant relief on the basis of a claim to rights which it is fairly confident would not be upheld at the trial. The more confident it is that the claimant will fail at the trial, the less likely it is that an interlocutory injunction will be appropriate."

Dealing with the particulars in Getmapping PIc $v$ Ordnance Survey, the judge did not find a convincing case for an abuse of dominance. Getmapping claimed that Ordnance Survey abused its dominant position by not placing Getmapping's digital photographs of the UK on its website or making them accessible to third parties. Laddie J. rejected this argument. Extending activities from a dominant market (supply of maps in the UK) into other markets (digital geographic images) did not

\footnotetext{
204 ibid para 61.

205 ibid para 51.

206 ibid para 66.

207 ibid para 65.

${ }^{208}$ Series 5 Software Ltd v Clarke \& Others (n 165).

${ }^{209}$ High Court of Justice, Getmapping Plc v Ordnance Survey [2002] U.K.C.L.R. 410; High Court of Justice, Suretrack Rail Services Ltd v Infraco JNP Ltd [2002] U.K.C.L.R. 3.

${ }^{210}$ Getmapping Plc v Ordnance Survey (n 210) para 28; Suretrack Rail Services Ltd v Infraco JNP Ltd (n 210) para 14.
} 
amount to an abuse of dominance nor did the fact that Ordnance Survey was publicly funded. ${ }^{211}$ The judge concluded that Getmapping's case is "very weak." ${ }^{212}$ Dealing briefly with the other prerequisites of interim relief, the court did not find the risk of irreparable harm in the light of Getmapping's future contract with Ordnance Survey about the supply of other digital images and statements that the former is able to meet competition from the latter. ${ }^{213}$

Similarly to his ruling in Getmapping PIc v Ordnance Survey, Laddie J. denied an application for an interim injunction in Suretrack Rail Services $L t d v$ Infraco JNP $L t d .{ }^{214}$ The application brought by Suretrack was rejected because it was an "extremely weak" case. ${ }^{215}$ The central question of the procedure was whether the defendant abused a dominant position by implementing a policy which excluded the plaintiff from offering protection masters to railway track contractors. Although the rejection of the application was likely to cause the plaintiff "grave hardship", the court found the case too weak to tip the balance of convenience in favour of the applicant. ${ }^{216}$ When a case is exceedingly weak or unarguable, it would not be right to grant it interlocutory relief no matter how strong the balance of convenience. ${ }^{217}$

In both decisions Getmapping PIc v Ordnance Survey and Suretrack Rail Services Ltd v Infraco JNP Ltd Laddie J. did not make any explicit reference to American Cyanamid. Arguably, the former case is a request for a mandatory rather than a prohibitory injunction while American Cyanamid dealt with an interim prohibitory injunction. However, in Suretrack the application could be qualified as either mandatory or prohibitory. ${ }^{218}$ It seems that independent from the type of injunction requested Laddie J. did not feel constrained by the American Cyanamid guidelines.

The American Cyanamid test was applied in Network Multimedia Television Ltd v Jobserve Ltd by Neuberger J. re-granting an interim injunction. ${ }^{219}$ The plaintiff applied for an order restraining the defendant from committing an alleged abuse of dominance under the UK Competition Act 1998. The initial injunction was granted on the basis of a without notice application. ${ }^{220}$ In its second ruling the

\footnotetext{
${ }^{211}$ Getmapping Plc v Ordnance Survey (n 210) para 45.

212 ibid para 57.

213 ibid para 58.

${ }^{214}$ Suretrack Rail Services Ltd v Infraco JNP Ltd (n 210).

215 ibid para 29.

216 ibid.

217 ibid para 15.

218 ibid para 14.

${ }^{219}$ High Court of Justice, Network Multimedia Television Ltd v Jobserve Ltd (Restored Injunction Hearing) [2001] U.K.C.L.R. 814.

${ }^{220}$ High Court of Justice, Network Multimedia Television Ltd v Jobserve Ltd (2000) 24 IPD 24038.
} 
court held that the applicant did not comply with its duty of full, fair and accurate disclosure and discharged the first interim injunction. Although the order was discontinued it was held appropriate to grant a fresh interim injunction. Applying for interim relief, the applicant must show good faith and disclose his case fully, fairly and accurately. This is particularly important in without notice applications. The case must be summarised identifying the crucial points. The applicant must draw "[...] the court's attention to significant factual, legal and procedural aspects of the case[...]" and disclose all facts which could be reasonably taken into account by the judge. ${ }^{221}$ If this duty is not observed, the judge may discharge the injunction even if, after a full enquiry, the order should have been granted. In the case of Network Multimedia the court found that the applicant did not comply with the high duty. Establishing a serious and culpable non-disclosure, the judge must then weigh the granting of a fresh injunction against the public interest that parties follow the duty to disclose. ${ }^{222}$ Making such a discretionary decision, the judge needs to take into account the degree and extent of the culpability with regard to the non-disclosure and the importance and significance to the outcome of the initial application. If the facts that were not disclosed would have lead to a different assessment and a refusal of the injunction, a fresh injunction should not be re-granted. ${ }^{223}$

As for the re-grant of the injunction, the plaintiff's case satisfied the American Cyanamid test. There was a serious issue to be tried; that is the question whether or not there was a dominant position in the relevant online advertising market and whether or not this position was abused. Avoiding hints as to the merits of the case, Neuberger J. followed the guidelines of American Cyanamid. Damages were not an adequate remedy because the plaintiff had to shut down its competing website if the defendant continued its threat. Furthermore, damages would be very difficult to calculate. The balance of convenience lied with the plaintiff although, the judge conceded, the discretion towards the re-grant of an injunction in the current case should be exercised "sparingly". ${ }^{224}$ The Court of Appeal confirmed the decision stressing the judge's discretion when (re-)granting an injunction. ${ }^{225}$ Dismissing the appeal of Jobserve, the Court of Appeal held with respect to the strength of the case that this is not a question for an interim procedure. ${ }^{226}$

\footnotetext{
${ }^{221}$ Network Multimedia Television Ltd v Jobserve Ltd (Restored Injunction Hearing) (n 220) para 28.

222 ibid para 24.

223 ibid para 48.

224 ibid para 105.

${ }^{225}$ Court of Appeal, Network Multimedia Television Ltd v Jobserve Ltd [2001] EWCA Civ 2021.

${ }^{226}$ ibid para 13. "At the end of the day Jobserve may turn out to be right. The question at this stage, however, is whether Network's case is seriously arguable. In my judgment, the court below was right to hold that it is. It is neither necessary nor appropriate to say any more than this in order to dispose of this appeal. The deputy judge in a full and careful judgment summarised the submissions of each side and concluded that there is a serious question to be tried. He clearly accepted Network's arguments as pointing to that conclusion. That is sufficient reasoning to support the result on an application for an interim injunction. As the balance of justice
} 
A relatively recent successful application for interim relief was made in the dispute between AdidasSalomon and the organisers of big tennis tournaments. In Adidas-Salomon AG $v$ Draper Adidas sought an interim prohibitory injunction against the dress-code decision of the defendants. ${ }^{227}$ The court held that there was a real prospect of success for Adidas' claim and a violation of Articles 101 or 102 (formerly Articles 81 and 82) by the defendant's decision. Damages were not an adequate remedy as future sales of sports equipment were unpredictable and past sales data do not provide a good proxy. For the same reason, however, the damages offered as cross-undertaking were insufficient for the competitors of Adidas. ${ }^{228}$ As for the status quo, the judge referred to the situation immediately preceding the decision of the defendants while the defendants argued that it should have been the time just before the order is issued. Overall, the court concluded that "[...] there are substantial grounds for the view that, notwithstanding their good intentions, the defendants have in the past and, if they apply the working definition, will in the future discriminate against Adidas by failing to apply their dress codes to other manufacturer's identifications. [...T] remedy for Adidas is to grant the injunctions it seeks."229

Interim injunctive relief can be refused if the plaintiff delays the application. The High Court of Justice rejected a request for a mandatory interim injunction in AAH Pharmaceuticals Ltd $v$ Pfizer $L t d .{ }^{230}$ The applicants asked the court to restrain Pfizer from terminating its supply agreements with the claimants and from refusing to supply the claimants with its prescription drugs. The court was very unhappy with the late application of the plaintiffs. In the light of the substantial evidence offered, the court said that there was no time left "to digest fully the factual and legal issues which arise. ${ }^{\prime 231}$ Despite finding a seriously arguable case - as far as possible in the short period of time available - there was no high degree of assurance that the plaintiffs will establish their right to injunction at trial. ${ }^{232}$ David Richards J. refused an injunction as this was likely to involve the least risk of injustice. ${ }^{233}$ As for the delay, the court found strong words of rebuke:

was in favour of granting an injunction, it was not appropriate for the court below and it is not appropriate for this court to express a view on the relative strengths of the arguments on the abuse point."

${ }^{227}$ High Court of Justice, Adidas-Salomon AG v Draper [2006] U.K.C.L.R. 823.

${ }^{228}$ ibid para 71.

229 ibid para 81.

${ }^{230}$ High Court of Justice, AAH Pharmaceuticals Ltd v Pfizer Ltd [2007] EWHC 565.

231 ibid para 46.

${ }^{232}$ David Richards J. referred to high degree of assurance for mandatory injunctions that was laid out in Nottingham Building Society v Eurodynamic Systems plc. High Court of Justice, Nottingham Building Society v Eurodynamics Systems plc [1992] F.S.R. 468.

${ }^{233}$ AAH Pharmaceuticals Ltd v Pfizer Ltd (n 231) para 75. 
"It is extraordinary for the court to be faced with an application of this complexity in relation to proposals which have been well-known both publicly and to the claimants for several months. It is a strong thing for the court to interfere by interim injunction in the conduct of business, particularly on the scale proposed in this case. By depriving the defendants and the court of the proper opportunity of dealing with this application, the delay greatly increases the risk of injustice if an injunction is granted. The fact that the claimants chose to pursue their complaints with the OFT and to persist in doing so until the very last moment does not in my judgment provide a good ground for not bringing the matter before the court at a much earlier stage. ${ }^{234}$

There has been at least one case where the plaintiff sought an interim injunction in conjunction with an anticipated acquisition (but not directly against the merger), Plessey Co Plc v General Electric Co Plc. ${ }^{235}$ The defendants agreed to make joint bid for the shares of the plaintiff. The plaintiff complained to the European Commission asserting that the agreement between the defendants to make a joint bid violates Article 101(1) (then Article 85(1)). Although an official investigation had been launched a final decision was not reached by the time the High Court decided on the interim order. Plessey sought, inter alia, an injunction constraining the defendants in acquiring or offering to acquire the defendant's share or to implement their agreement because it violates Article 101. Moritt J. held that, following American Cyanamid and NWL Ltd $v$ Woods, a serious issue was to be tried and damages were not adequate for neither party. As for the balance of convenience, the court decided, relying on Lord Diplock in NWL Ltd $v$ Woods, in favour of the defendants. A contrary decision would have been a final judgement in favour of the plaintiff. The period of uncertainty and, consequently, damages for the plaintiff is acceptable in these circumstances. ${ }^{236}$

\section{Preliminary conclusion}

Permanent injunctions are a remedy that is seldom used before the English courts. Admittedly, we do not know how many negative or positive requests are settled out of court. Thus, it is difficult to draw any conclusions with respect to permanent injunctions. One point that catches the eye, especially in conjunction with interim relief, is the adequacy of damages. This criterion is rather difficult to disprove in most instances and may deter plaintiffs from seeking injunctions as long as damages are theoretically obtainable. Courts also seem to be reluctant to interfere with the negotiations of contracts.

\footnotetext{
${ }^{234}$ ibid para 77.

${ }^{235}$ High Court of Justice, Plessey Co PIc v General Electric Co PIC [1998] ECC 384.

${ }^{236}$ ibid para 60.
} 
In contrast to perpetual injunctions, interim injunctions were sought more often. ${ }^{237}$ One crucial element of cases in which an application for interim relief succeeded was the likelihood that the plaintiff's business had to exit the market if the interim injunction was not granted. This was the case in Cutsforth, Software Cellular Network, Holleran and Network Multimedia. In Adidas-Salomon it was the impossibility of calculating potential damages the lead to the grant of interim relief. The decision in Attherace seems to be somewhat in between the risk of a market exit and the difficulties of calculating damages with the judge referring to the "loss of business." Generalising this observation, one can argue that interim injunctions are successful when the plaintiff can show that his business is in danger. There might be other cases in which damages are not an adequate remedy but the bar appears to be set high. The decision in Network Multimedia Television may give the impression that it is not difficult to obtain an interim injunction even if the applicant did not fully comply with the duties of fairness and disclosure. However, this case, like most cases, is underpinned by the argument that the applicant would have been driven out of the market if an interim remedy had not been granted.

Most cases took place in the context of contracts or failed contract negotiations. This means cases that involved allegations of illegal vertical restraints or the abuse of dominance. In Plessey, a case that seems to be the odd one out, the plaintiffs asserted unsuccessfully a horizontal anticompetitive agreement between the defendants to fend off a hostile takeover. When applicants asserted the leverage of market power (Claritas and Getmapping), judges were rather hesitant to confirm the anticompetitive effects story. Failing to convince the court of the adverse effects, the plaintiffs did not show that a serious issues was tried or, in the case of Getmapping, that there was a prospect of success in the trial.

Although the standard test applied to requests for injunctive relief is American Cyanamid, there have been a number of cases in which judges either ignored these guidelines or did not find them applicable. Notable decisions are the two cases decided by Laddie J. (Getmapping and Suretrack) but also Sockel in which the courts assess the success of the application in a potential trial dissenting from American Cyanamid which explicitly rejected an assessment of the future success of the claim. Whether or not the prospect of success makes it easier or more difficult for potential applicants probably depends on the nature and amount of evidence judges require. One can probably assume that judges normally form an opinion about the prospect of success independent from the test

\footnotetext{
${ }^{237}$ In the proceedings of Hendry $v$ World Professional Billiards \& Snooker Association Ltd the High Court also heard an application for interim relief. It was dealt with on undertakings. High Court of Justice, Hendry $v$ World Professional Billiards \& Snooker Association Ltd [2001] U.K.C.L.R. 5.
} 
applied. The hardest test a plaintiff can face is the high degree of assurance in requests for mandatory interim relief.

Overall, it might be troublesome to obtain an interim injunction, let alone perpetual relief, as it is hard to convince the courts to grant interim remedies and to bring complex economic evidence in interim hearings. Assessing the situation before the modernisation of UK competition law, Rodger and MacCulloch found that the damages hurdle is probably the most difficult to clear. ${ }^{238}$ The current practice refuses the plaintiff an attractive alternative to costly damages claims. Lord Wilberforce, who dissented in Garden Cottage Foods, expressed the problem like this:

"If [...] the plaintiff company's right to damages is an uncertain one, that would be, in itself, a strong ground for not leaving the plaintiff company to recover hypothetical damages at the trial but for granting an injunction."239

The practice of the English courts to grant interim injunctions has also been criticised in the light of European law. Referring to the principle of effectiveness, Cumming argued for an extension of interim relief beyond just the minimum level. ${ }^{240}$ In his view, the principle of effectiveness provides for an alternative legal basis for an interim injunction. He also asserted that the balance of convenience is an inadequate standard for interim relief and an assessment of applications for interim relief should take into accounts the merits of the case. ${ }^{241}$ Recently, Rodger pointed out that the difficulties of obtaining interim relief may also disincentivise victims from bringing claims to the court in the first place. ${ }^{242}$

\section{F. Comparing injunctive relief in Germany and England and Wales}

While criticism against the current practice of granting interim relief was mounted in England, there were relatively few negative comments about the availability of permanent and preliminary injunctive relief in Germany. The comparison of English and German antitrust injunctions showed

\footnotetext{
${ }^{238}$ Rodger and MacCulloch (n 4) 397.

${ }^{239}$ Garden Cottage Foods Ltd v Milk Marketing Board (n 168) 152.

240 "Assistance, therefore, is required from the doctrine of effectiveness in the sense of it being extended to provide effective enforcement which is not just minimal but adequate. Accordingly, it is submitted that it might be possible to apply the doctrine of effectiveness in the instant case of the two different legal bases for interim relief in the CPR [Civil Procedure Rules]."Cumming, Spitz and Janal (n 23) 36.

241 ibid 165

${ }^{242}$ Rodger (n 130) 72.
} 
more than that though. Both jurisdictions generally provide for both interim and permanent injunctive relief. However, the legal prerequisites differ and may explain, to some extent, the varying impact of injunctions on private enforcement of the antitrust laws.

As for the alleged anticompetitive conduct that underpins injunctive relief requests, there seem to be parallels between the jurisdictions. Most cases were based on allegations of either the abuse of market power or anticompetitive vertical restraints. Especially the access to essential facilities and the refusal to contract triggered injunction claims. This may be explained by the purpose of damages claims which is to compensate past losses. They are less useful though in order to gain access to an essential facility with effect for the future, unless the threat of damages has such a strong deterrence effect that it forces the defendant into renegotiation of contract terms. Although we have no information about the precise level of deterrence stemming from damages payments, one could think that the current deterrence effect is relatively weak with regards to refusals to deal and discrimination. Bringing a damages claim before the judge, the plaintiff needs to prove forgone profits or potential losses; a tedious and not very promising venture. The type of anticompetitive conduct asserted in injunctive relief proceedings also strengthens my argument that damages actions are particularly useful against cartels but may be not the plaintiff's first choice against other types of infringements. In cases where the defendant entered into an anticompetitive vertical agreement or abused a position of dominance, the plaintiff is satisfied with injunctive relief. Giving victims of anticompetitive behaviour access to the defendant's property (network) or interfering with contracts may also exert a deterrence effect which could exceed the deterrence effect of damages. Assumed that it is next to impossible to precisely calculate economic losses, it may hurt and deter the violator more (in the absence of a damages multiplier) if he has to grant access to an essential facility instead of paying out damages that are, in all likelihood, lower than the profit gained from the infringement. Further analysis is needed to actually answer the questions whether or not injunctive relief deters the violation of antitrust laws by threatening an interference with the potential perpetrator's contract or property.

The analysis of the content of injunctions has shown that cases in which plaintiffs seek an antitrust injunction against alleged vertical restraints or an abuse of dominance are often related to contract disputes. This was observed in both England and Germany. However, there is a different approach to this problem in these jurisdictions. English judges seemed to be aware of the fact that this type of antitrust litigation is also a consequence of failed negotiations rather than just a violation of an antitrust provision. Occasionally, they expressed their unease about the claim being brought as an 
antitrust dispute, like Etherton J. did in Attherace $v$ British Horseracing Board.$^{243}$ The issue of contracts in antitrust law suits has been of lesser concern to their German colleagues. At least the case law does not indicate an awareness of or reluctance towards plaintiffs who resort to antitrust remedies in order to solve contractual conflicts. As I have mentioned before, the attitude towards antitrust contract litigation may not be important as long as the rules and consequences for antitrust and contract disputes do not differ.

The differing attitude of judges towards the interference with contracts and, thus, the grant of antitrust injunctive relief provides the starting point for an interesting interpretation of how the law is applied in a civil law and a common law jurisdiction. If we follow the approach suggested by La Porta et al., ${ }^{244}$ it is not only a question of the availability of injunctions but also the legal systems that determines the usage thereof. Analysing the judiciary in the context of corporate governance and finance, they claim that common law is associated with lower formalism of judicial procedures ${ }^{245}$ and greater judicial independence than civil law. ${ }^{246}$ These indicators are in turn associated with better contract enforcement and greater security of property rights. ${ }^{247}$ It is argued that common law supports private market outcomes, which are supposed to be the most efficient outcomes, while civil law systems stand for the implementation of policies to achieve desired outcomes rather than efficient ones. ${ }^{248}$ Having observed the unease with which judges interfered with contracts or failed negotiations in England, there might be some support for the argument that contracts (or the freedom to contract) are better enforced or protected before English common law courts. Apparently, German courts have fewer objections against the mixing of antitrust and negotiation issues. Since antitrust injunctive relief is a remedy that is often used to change contract terms or to force the other side into a contract on the basis of an antitrust violation, La Porta's et al. arguments may be an explanation for my observations. On the other hand, one could argue that competition policy is supposed to maintain or re-establish competition in the markets, thus, maintaining competitive conditions which in turn will lead to efficient outcomes. Consequently, there are two contradicting lines of argument with regards to the granting of antitrust injunctions. One could say that the reluctance of English judges to grant an injunction preserves efficient market outcomes. But one can also argue that the widespread use of antitrust injunctions in Germany helps to implement

\footnotetext{
${ }^{243}$ Attheraces v British Horseracing Board (n 154) para 7.

${ }^{244}$ La Porta, Lopez-de-Silanes and Shleifer (n 7).

${ }^{245}$ Simeon Djankov and others, 'Courts' (2003) 118 The Quarterly Journal of Economics 453.

${ }^{246}$ Rafael La Porta and others, 'Judicial Checks and Balances' (2004) 112 The Journal of Political Economy 445.

${ }^{247}$ La Porta, Lopez-de-Silanes and Shleifer (n 7) 286. At the same time, the authors admit that there are high costs of litigation in common law countries and a higher standard of living in civil law countries which they cannot explain.

248 ibid.
} 
competition policy and protect competition in the markets resulting in efficient outcomes. ${ }^{249}$ To solve this riddle one would need to (be able to) measure the efficiency of outcomes in a sample of injunction claims from both jurisdictions.

Comparing the legal requirements for antitrust injunctive relief in a common law and a civil law country, there is an alternative explanation for the more lenient approach of judges in Germany offered by the work of Arrighetti, Bachmann and Deakin. ${ }^{250}$ According to their study of firms and contracts in the UK, Italy and Germany, contracts between firms in Germany were the most formalised in their sample. Breaches of contract terms often led to trial and German firms were much clearer about the cost and outcome of litigation than firms in England. ${ }^{251}$ The authors concluded that the impact of contract law depends, inter alia, on the institutional framework. Building up on their findings, judges in Germany seem to be more used to contract issues being brought before them. Therefore, they may feel less reluctant, compared to their English colleagues, to rule on issues that affect the freedom to contract and property rights. The institutions for contract enforcement; that is formalised contracts and judges being experienced with (antitrust) contract disputes, may explain the outcome of my study: stricter tests for injunctive relief in England and a more relaxed approach towards the grant of injunctions in contract disputes in Germany. The majority of antitrust injunction claims are based on either vertical restraints or the abuse of dominance. Most of these types of anticompetitive conduct appear in contracts or can be used to force the defendant into a contract.

A major difference between England and Germany is the legal foundation for injunctive relief. Injunction and removal claims in Germany are granted as of right. Like their English counterparts, German courts exercise some discretion when, for example, testing the prospect of success the plaintiff's application would have in a future trial or assessing and determining the required prima facie evidence. However, there is no doubt about the availability of injunctive relief if the legal conditions for the respective injunction claim are met. In contrast to Germany, injunctions of both interim and perpetual nature are in the discretion of the judge in England. On the one hand, this provides for more judicial freedom to adopt an approach suitable for the facts being presented. On the other hand, it seems to have led to a rather restrictive approach and uncertainty about the grant of injunctions. Combined with the reluctance of judges to award other than damages remedies, this

\footnotetext{
${ }^{249}$ This requires that the competition policy is sound and does not embody, for instance, elements of industrial policy to create or protect 'national champions'.

${ }^{250}$ Alessandro Arrighetti, Reinhard Bachmann and Simon Deakin, 'Contract Law, Social Norms and Inter-firm Cooperation' (1997) 21 Cambridge Journal of Economics 171-195.

${ }^{251}$ ibid 188.
} 
may be one particular reason for the reservation on part of the plaintiffs to file for injunctive relief. It is easy though to overstate the discretionary nature of injunctive relief in England as a cause for the observed difference in litigation patterns. The English courts have established the conditions to which permanent and interim relief is to be granted. Furthermore, there have been instances in which English judges held that injunctions were an appropriate remedy. It is also likely that it is the courts' reluctance to grant injunctive relief rather than the discretionary nature of injunctions hampering the bringing of private cases.

Being an equitable remedy, injunctions in the England require that the plaintiff shows that damages are not an adequate remedy. This has been described as one of the major obstacles. ${ }^{252}$ Compared to damages, injunctive relief seems to be of a secondary rank. There are very few situations, especially in interim proceedings, in which damages are not appropriate. Being driven out of business so that a later affirmative judgement becomes pointless or the difficulties of calculating a potential damages award satisfied this criterion. Ordinary problems of damages calculation do not render damages inadequate. It seems a rather difficult standard to meet. German law does not require the judge to test injunctive relief against the availability of another remedy. Injunctions are awarded as a remedy on their own. This may be a reason for the overwhelming number of injunctions claims that are brought in Germany. ${ }^{253}$

When dealing with interim injunction requests in Germany, judges assess the potential prospect of success of the application in trial. Plaintiffs in England only need to show that a serious issue is to be tried. In the light of American Cyanamid ${ }^{254}$ this appears to require less from the applicant compared to the German test. Some English judges have departed from the American Cyanamid standard, which only applies to prohibitory interim injunctions anyway, and tested the prospect of success. ${ }^{255}$ Whether or not this is a more general trend towards the convergence of legal standards cannot be said. American Cyanamid still stands and rejects the prospect of success as a criterion for the assessment of applications for prohibitory interim relief. As for the balancing of hardship which will be on the parties, courts in both countries engage in some kind of weighing process. English judges do this at the 'balance of convenience' level. German judges may adjust the evidence requirements depending on the effect the interim measure might have. We have observed a more cautious approach towards mandatory interim injunctions in both jurisdictions. English courts developed

\footnotetext{
252 Rodger and MacCulloch (n 4) 397.

253 Peyer (n 59).

${ }^{254}$ American Cyanamid Co. v Ethicon Ltd. (n 161).

${ }^{255}$ Getmapping PIc v Ordnance Survey (n 210); Suretrack Rail Services Ltd v Infraco JNP Ltd (n 210).
} 
different standards for prohibitory and mandatory interim relief with the latter standard being more restrictive for the applicant. Mandatory interim injunctions are by far the most intrusive remedy and are sometimes met with suspicion. Although German courts have expressed their reserve, there were cases in which the defendant was asked to do something on a preliminary basis. The rather lenient approach of German judges when granting mandatory but also prohibitory injunctive relief may increase the risk of false positives, especially in interim proceedings. Comparing antitrust proceedings between England and Germany, one must also take into account the different purposes of civil procedure. This may be a reason for the cautious approach of English judges towards interim remedies. The main purpose of civil procedure in continental Europe is not to establish the truth through exhaustive fact finding as it is in the UK. The objective is to protect private rights. ${ }^{256}$ As preliminary proceedings do not allow a full assessment of the facts, the discomfort of English judges with interim injunctions becomes more understandable. Judges often resorted to the fact that they could not fully assess the evidence or that not all necessary evidence could be offered in trial.

Actions for injunctive relief in England are predominantly requests for interim injunctions while a greater number of injunctive relief actions in Germany deal with permanent injunctions and removal claims. German law divides injunctive relief into removal claims and 'real' injunction claims although in practice this distinction is not always adhered to. Existing contracts or failed negations underpin most of the injunctive relief actions I have scrutinised. The legal tests differ across both countries especially with regards to the adequacy of damages required in England. In both jurisdictions the plaintiffs have to clear stricter tests if mandatory injunctive relief is sought while judges appear to be more lenient with requests for prohibitory injunctions. Whether or not it is just the varying strength of the legal tests that led to the differing significance of injunctions in private antitrust enforcement cannot be said without further assessment of the case law. It may be a crucial factor though. Overall, the conditions for the grant of injunctive relief differ significantly between England and Germany.

\section{G. Concluding remarks}

The comparison of German and English antitrust injunctions has shown a considerable diversity of legal rules between these two jurisdictions. Apart from different origins of injunctive relief and

\footnotetext{
${ }^{256}$ Rolf Stürner, 'Duties of Disclosure and Burden of Proof in the Private Enforcement of European Competition Law' in Jürgen Basedow (ed), Private Enforcement of EC Competition Law (Kluwer Law International, Alphen a. d. Rijn 2007) 163, 177.
} 
varying legal tests, there seem to be a different attitude towards antitrust injunctive relief which may be traced back to the general differences between common law and civil law systems.

Despite the criticism that can be issued against a widespread use of injunctive relief, it appears to be a remedy that, if applied in the right dose, could help private antitrust enforcement to break the deadlock if such deadlock exists. This study has shown that an injunction may prove a particularly valuable remedy in cases involving the abuse of dominance or vertical restraints but less so in instance of violations of the cartel prohibition. ${ }^{257}$ The German experience suggests that injunctive relief can be a favourable remedy since it does not require the proof of causation or the amount of damages. ${ }^{258}$ But also the English High Court of Justice pointed out that, with reference to Article 102, there are cases in which the only form of relief with any real value to the plaintiff are injunction orders. ${ }^{259}$ From an efficiency point of view, injunctions can be an attractive alternative since the courts do not need to compute damages. If one views an injunction as an instruction to the parties to resolve their disputes through voluntary exchange, then it is an attractive remedy against private nuisances. $^{260}$

Although injunctions in England and Germany are utilised to varying degrees for the abovementioned reasons, the neglect of this remedy on the policy level is astonishing. Public enforcement agencies like the German Federal Cartel Office have repeatedly pointed out that private enforcement benefits from injunctions. Plaintiffs who seek injunctive relief often pick up smaller cases that cannot be pursued by the authorities. ${ }^{261}$ This poses the more general questions what role injunctions are supposed to play in the overall antitrust enforcement scheme. Injunctive relief does not contribute to the compensation of plaintiffs but it may threaten the perpetrator, for example, with the intrusion into property rights or contractual freedom. It could also be regarded as a tool to remediate victims but this would require incorporating remediation into the main goals of

\footnotetext{
${ }^{257}$ Komninos also sees the utility of injunctions in actions against the abuse of dominance Komninos $(n 4) 215$.

${ }^{258}$ Thomas Eilmansberger, 'The Green Paper on Damages Actions for Breach of the EC Antitrust Rules and Beyond: Reflections on the Utility and Feasibility of Stimulating Private Enforcement Through Legislative Action' (2007) 44 CMLR 431-478, 437.

${ }^{259}$ Maclntyre (n 2) 32; Sockel GmbH v The Body Shop International PIc (n 195) 11.

${ }^{260}$ Robert Cooter and Thomas S Ulen, Law \& Economics (5 ${ }^{\text {th }}$ edn Pearson/Addison Wesley, Boston 2008) 176.

${ }^{261}$ Ulf Böge, 'Public and Private Enforcement: Harmony or Discord' (2006) 5 Competition Law Journal 114-122, 121.
} 
private antitrust enforcement. ${ }^{262}$ Komninos suggested including an injunctive objective in the objectives of private antitrust enforcement. ${ }^{263}$

Overall, the conditions for the grant of injunctive relief differ significantly between England and Germany. There is no level playing field for private actions aimed at injunctive relief in the Member States. This poses the question whether the European Commission is right only focusing on damages actions in its attempt to create similar conditions for private antitrust claims in the Member States. As this study has shown, antitrust injunctions are also a useful tool to enforce the antitrust laws. Nevertheless, they are excluded from the claim-facilitating policy proposals without further justification. The lack of a level playing field does not only exist with regards to damages action. The conditions that must be met to obtain an injunctive relief order are not only different between England and Germany but probably vary in other Member States, too. The substantial differences with regards to the awarding of injunctive relief between Germany and England and Wales may, to some extent, explain the differences in the magnitude of private antitrust enforcement. It seems that the real value of antitrust injunctions has not been discovered yet or was already forgotten.

\footnotetext{
${ }^{262}$ First mentions such an objective in the context of US private antitrust. Harry First, 'The Case for Antitrust Civil Penalties' (2010) 76 Antitrust Law Journal, Forthcoming 127-166, 26.

${ }^{263}$ Assimakis P Komninos, 'Public and Private Antitrust Enforcement in Europe: Complement? Overlap?' (2006) 3 Competition Law Review 5-26, 8.
} 